\title{
Characterisation of the ERF102 to ERF105 genes of Arabidopsis thaliana and their role in the response to cold stress
}

\author{
Sylvia Illgen ${ }^{1} \cdot$ Stefanie Zintl ${ }^{1}$ Ellen Zuther ${ }^{2} \cdot$ Dirk K. Hincha $^{2} \cdot$ Thomas Schmülling $^{1}$ (i)
}

Received: 22 November 2019 / Accepted: 4 March 2020

(c) The Author(s) 2020

\begin{abstract}
Key message The four phylogenetically closely related ERF102 to ERF105 transcription factors of Arabidopsis thaliana are regulated by different stresses and are involved in the response to cold stress.

Abstract The ETHYLENE RESPONSE FACTOR $(E R F)$ genes of Arabidopsis thaliana form a large family encoding plantspecific transcription factors. Here, we characterise the four phylogenetically closely related ERF102/ERF5, ERF103/ERF6, ERF104 and ERF105 genes. Expression analyses revealed that these four genes are similarly regulated by different hormones and abiotic stresses. Analyses of tissue-specific expression using promoter: GUS reporter lines revealed their predominant expression in root tissues including the root meristem (ERF103), the quiescent center (ERF104) and the root vasculature (all). All GFP-ERF fusion proteins were nuclear-localised. The analysis of insertional mutants, amiRNA lines and 35S:ERF overexpressing transgenic lines indicated that ERF102 to ERF105 have only a limited impact on regulating shoot and root growth. Previous work had shown a role for ERF105 in the cold stress response. Here, measurement of electrolyte leakage to determine leaf freezing tolerance and expression analyses of cold-responsive genes revealed that the combined activity of ERF102 and ERF103 is also required for a full cold acclimation response likely involving the CBF regulon. These results suggest a common function of these $E R F$ genes in the response to cold stress.
\end{abstract}

Keywords Arabidopsis thaliana - Cold acclimation · ETHYLENE RESPONSE FACTOR genes · Freezing tolerance · Root architecture $\cdot$ Transcription factor

\section{Introduction}

The $E R F$ genes encode plant-specific transcription factors forming a large gene family with 122 members in Arabidopsis thaliana (Nakano et al. 2006). The ERF transcription factors are members of the APETALA2/ETHYLENE RESPONSE FACTOR (AP2/ERF) superfamily, which also contains the AP2 and RAV families and which is defined by the AP2/ERF DNA-binding domain (Riechmann et al.

Electronic supplementary material The online version of this article (https://doi.org/10.1007/s11103-020-00993-1) contains supplementary material, which is available to authorized users.

Thomas Schmülling

tschmue@zedat.fu-berlin.de

1 Institute of Biology/Applied Genetics, Dahlem Centre of Plant Sciences (DCPS), Freie Universität Berlin, Albrecht-Thaer-Weg 6, 14195 Berlin, Germany

2 Max-Planck-Institute of Molecular Plant Physiology, 14476 Potsdam, Germany
2000). This domain is about 60 amino acids long and forms an interface of three antiparallel $\beta$-strands and one $\alpha$-helix (Ohme-Takagi and Shinshi 1995). The $\beta$-strands bind to an 11 bp consensus sequence (5'-TAAGAGCCGCC- 3 '), the GCC-Box, in the major groove of the DNA double helix (Hao et al. 1998). ERF transcription factors are involved in the regulation of numerous developmental processes (Riechmann and Meyerowitz 1998) and they are important for the response to various biotic and abiotic stresses including cold (Kizis et al. 2001; Agarwal et al. 2006b; Srivastava and Kumar 2019; Xie et al. 2019).

Previously, we identified four phylogenetically closely related $E R F$ genes with similar transcriptional responses to cytokinin (Brenner et al. 2005). These genes, ERF102 (AT5G47230; known as ERF5), ERF103 (AT4G17490; identical to ERF6), ERF104 (AT5G61600) and ERF105 (AT5G51190) are members of group IXb of the ERF family (Nakano et al. 2006). Expression of ERF102 to ERF105 is regulated by cold and different cold stress-related hormones, and it was demonstrated that ERF105 has a function in the 
freezing tolerance and cold acclimation of Arabidopsis (Bolt et al. 2017). All four $E R F$ genes are also involved in the response to other stresses. ERF102 and ERF103 regulate leaf growth inhibition upon mild osmotic stress (Dubois et al. 2013, 2015) and ERF103 additionally regulates oxidative stress responses (Sewelam et al. 2013). ERF103, ERF104 and ERF105 are involved in the fast retrograde signalling response and the acclimation response to high light (Moore et al. 2014a, b; Vogel et al. 2014). Further studies have shown that ERF102 to ERF105 play a role in plant immunity (Bethke et al. 2009; Moffat et al. 2012; Son et al. 2012; Mase et al. 2013; Meng et al. 2013; Cao et al. 2019). Thus, ERF102 to ERF105 match the profile of other ERF transcription factors designated as a regulatory hub integrating hormone signalling in the plant response to abiotic stresses (Müller and Munné-Bosch 2015).

The close phylogenetic relationship among the four $E R F$ genes and the similarity of their transcriptional responses to different cues suggested that they share some common functions in response to cold. Cold stress adversely affects plant growth and development and several pathways to respond to cold stress have been described. Plants from temperate and boreal climates have evolved mechanisms to acquire freezing tolerance through cold acclimation, a process in which upon exposure to low non-freezing temperatures the ability to survive freezing temperatures increases (Xin and Browse 2000). A central cold signalling pathway is the CBF (C-REPEAT-BINDING FACTOR/DEHYDRATIONRESPONSE ELEMENT-BINDING PROTEIN) regulon. The CBF1 (DREB1b), CBF2 (DREB1C) and CBF3 (DREBIa) genes are the central regulatory elements of this regulon (Liu et al. 1998; Chinnusamy et al. 2007). The INDUCER OF C-REPEAT-BINDING FACTOR EXPRESSION 1 (ICE1), a MYC-type bHLH (basic helix-loop-helix) transcription factor, is post-translationally activated in response to cold (Chinnusamy et al. 2003; Miura et al. 2007; Ding et al. 2015; $\mathrm{Li}$ et al. 2017). ICE1 in turn activates the transcription of the $C B F 3$ gene (Chinnusamy et al. 2003). Besides ICE1, expression of the cold-regulated $C B F$ genes is positively controlled by several other transcription factors including ICE2 and CALMODULIN-BINDING TRANSCRIPTION ACTIVATOR 3 (CAMTA3) (Doherty et al. 2009; Fursova et al. 2009). Negative regulators of the $\mathrm{CBF}$ regulon are, for instance, the $\mathrm{C} 2 \mathrm{H} 2$ zinc finger transcription factor ZAT12 (Vogel et al. 2005) and MYB15 (Agarwal et al. 2006a). MYB15 is in turn negatively regulated by ICE1 (Agarwal et al. 2006a) and phosphorylation of MYB15 by MPK6 reduces its affinity to bind to the $C B F 3$ promoter (Kim et al. 2017). The CBF proteins regulate the expression of the COLD-REGULATED (COR) genes and physiological responses (e.g. accumulation of cryoprotective compounds, modification of cellular structures) that together confer cold acclimation (Thomashow 1999; Yamaguchi-Shinozaki and
Shinozaki 2006). Transcriptomic analyses of the CBF regulon has revealed that only part $(\sim 11 \%)$ of the cold-responsive genes is under control of the CBF regulon (Park et al. 2015), which was confirmed by gene expression analysis in $c f b$ triple mutants (Jia et al. 2016; Zhao et al. 2016). It was concluded that only about one-third of the increase in freezing tolerance that occurs in response to low temperature is dependent on the CBF regulon (Park et al. 2015). Together, this suggests that an extensive regulatory network involving numerous transcription factors in addition to the best known $\mathrm{CBF}$ core regulators governs the response to cold.

We previously identified the ERF 105 gene of Arabidopsis as an important factor for Arabidopsis freezing tolerance and cold acclimation (Bolt et al. 2017). The strongly reduced expression of cold-responsive genes in ERF105 mutants upon cold acclimation suggests that its action is linked to the $\mathrm{CBF}$ regulon. Also the expression of three closely related transcription factor genes, ERF102, ERF103 and ERF104, is induced by cold (Lee et al. 2005; Vogel et al. 2005; Park et al. 2015; Bolt et al. 2017). It is therefore possible that these transcription factors have a function in the response to cold stress. Here, we have extended our analysis of the ERF105 gene family. We provide additional transcript data supporting a similar response profile of the ERF 105 family members and show the tissue-specific expressions of pERF102:GUS to $p E R F$ 104:GUS as well as the subcellular localisations of GFP-ERF102 to GFP-ERF104 fusion proteins. Single and combined loss-of-function mutants and lines overexpressing single $E R F$ genes were analysed for their growth characteristics and cold stress response and reveal partially similar functions of the members of this transcription factor subfamily.

\section{Results}

\section{Phylogenetic analysis and description of the ERF102 to ERF105 proteins of Arabidopsis thaliana}

According to 'The Arabidopsis Information Resource' (TAIR) (Huala et al. 2001), ERF102 to ERF105 are relatively small, intronless genes with coding regions for proteins containing 300 (ERF102), 282 (ERF103), 241 (ERF104) and 221 (ERF105) amino acids. Like all AP2/ERF transcription factors they possess the characteristic AP2/ERF domain and are the only proteins in group IX with one (ERF102 and ERF103) or two (ERF104 and ERF105) putative phosphorylation sites (Nakano et al. 2006). Moreover, ERF102 to ERF105 possess acidic regions that might function as transcriptional activation domains (Fujimoto et al. 2000). According to WoLF PSORT (Horton et al. 2007) ERF103 has a single nuclear localisation signal (NLS) whereas ERF102, ERF104 and ERF105 have two NLS (Fig. 1a). 
(A)

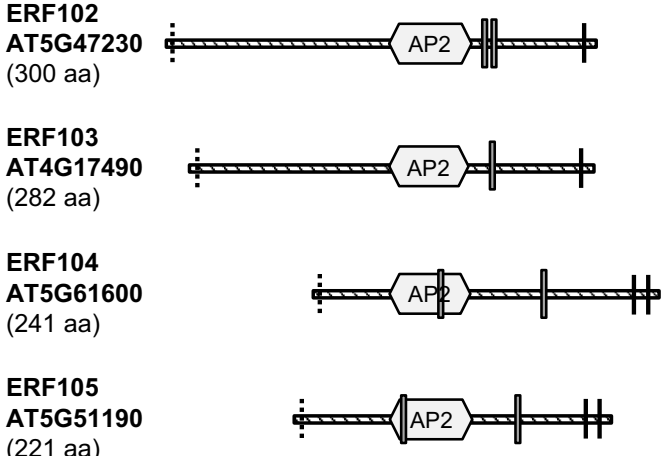

(B)

IXb

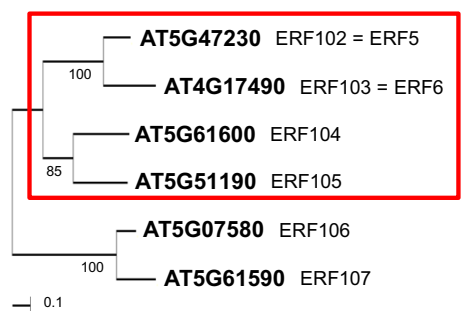

Fig. 1 Description of the ERF102 to ERF105 proteins of Arabidopsis thaliana. (a) Structure of the Arabidopsis ERF102 to ERF105 proteins. The schematic representation shows the protein structures of ERF102 to ERF105 according to Nakano et al. (2006). The striped lines represent the protein sequences, the hexagons indicate the AP2/ ERF DNA-binding domain, black lines putative phosphorylation sites, dashed lines the putative transactivation domains (Nakano et al.

Comparison of the amino acid sequences of ERF102 to ERF105 using MUSCLE (Edgar 2004) revealed a sequence identity of $40 \%$ between all four proteins with high conservation of the AP2/ERF domain. The protein pairs share $67 \%$ (ERF102 and ERF103) and 52\% (ERF104 and ERF105) amino acid identity. Phylogenetic analysis confirmed that ERF102 to ERF105 are closely related, with ERF102 and ERF103 together on one branch and ERF104 and ERF105 on the other branch of the phylogenetic tree (Fig. 1b).

\section{The ERF102 to ERF105 transcription factor genes show a similar transcriptional regulation pattern}

Analysis of transcriptional regulation may yield indications on functional context, therefore the previous work showing that ERF102 to ERF105 are regulated similarly by cold and different cold stress-related hormones, including ethylene, jasmonate and abscisic acid (Bolt et al. 2017), was extended. First we complemented the comparison of the hormonal transcriptional regulation of the four $E R F$ genes and analysed their response to auxin and salicylic acid (SA). Auxin (NAA) rapidly and strongly induced the transcript abundances of all four $E R F$ genes about 180-fold (ERF102), 100-fold (ERF103), 13-fold (ERF104) and 130fold (ERF105) after $30 \mathrm{~min}$. This increase was transient as $2 \mathrm{~h}$ after auxin treatment the transcript abundances were only increased between 11-fold (ERF102) and twofold (ERF105) (Fig. 2a). In contrast, the transcript levels of all four $E R F$ genes were downregulated by SA to about $50 \%$ of the initial level after $2 \mathrm{~h}$ (Fig. 2b).

Next, the response to different stress treatments was studied. Heat stress $\left(42{ }^{\circ} \mathrm{C}\right)$ induced an
2006) and grey boxes the nuclear localisation signals determined with WoLF PSORT (Horton et al. 2007). (b) An unrooted phylogenetic tree of group IXb ERF transcription factors showing the close evolutionary relationship between ERF102 to ERF105 (red box) that are studied. The phylogenetic tree was constructed using MEGA6, the numbers indicate bootstrap values (Tamura et al. 2013)

upregulation of ERF104 and ERF105 of about fivefold and eightfold, respectively, after $2 \mathrm{~h}$ (Fig. 2c). High light $\left(1000 \mu \mathrm{mol} \mathrm{m} \mathrm{m}^{-2} \mathrm{~s}^{-1}\right)$ provoked a rapid upregulation of all four genes about fourfold (ERF102), threefold (ERF103 and ERF104) and 4.5-fold (ERF105) after $30 \mathrm{~min}$. The transcripts were back to their initial levels after $2 \mathrm{~h}$ (Fig. 2d). Oxidative stress imposed by $\mathrm{H}_{2} \mathrm{O}_{2}$ treatment resulted in a rapid upregulation of all four genes after $15 \mathrm{~min}$ by about 3.5-fold (ERF102), 4.5-fold (ERF103), 6.5-fold (ERF104), and 8.5-fold (ERF105). After $2 \mathrm{~h}$ transcript levels were increased further to about fivefold (ERF102), ninefold (ERF103), tenfold (ERF104) and 12-fold (ERF105) compared to the initial level (Fig. 2e). Oxidative stress imposed by treatment with the superoxide-generating herbicide paraquat showed a similar result (Fig. 2f). A fast transcriptional response of the ERF genes was also observed after drought stress that led to an about twofold (ERF102 and ERF104), 3.5-fold (ERF103) and 5.5-fold (ERF105) upregulation of transcript levels within $15 \mathrm{~min}$, which were decreased again after $1 \mathrm{~h}$ (Fig. $2 \mathrm{~g}$ ). Salt stress $(200 \mathrm{mM} \mathrm{NaCl})$ also caused a rapid but transient upregulation of the $E R F$ genes up to about six- to seven-fold for the ERF102, ERF103 and ERF 105 genes (Fig. 2h). Two of the genes (ERF102, ERF105) also responded rapidly to mannitol application (Fig. 2i).

We have analyzed the occurrence and distribution of cis-acting response elements (CAREs) in $2 \mathrm{~kb}$ of the promoters 5' upstream of all four ERF genes. Table $\mathrm{S} 1$ shows the frequency of a representative but non-exhaustive list of CAREs functionally related to the regulation of the ERF102 to ERF105 genes by hormonal and environmental cues documented in Fig. 2 and Bolt et al. (2017). Fig. S1 illustrates the 
(A)

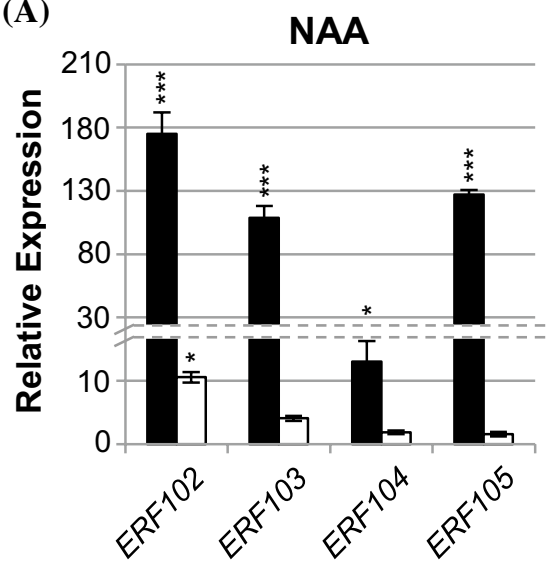

- $30 \min \square 2 \mathrm{~h}$

(D)

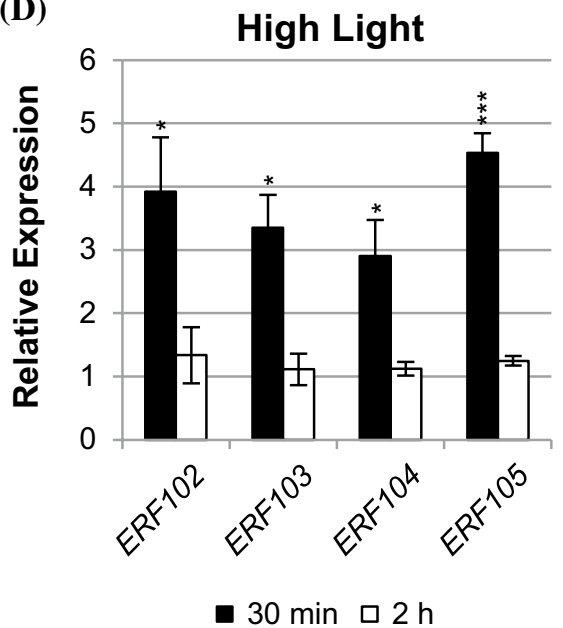

(G)

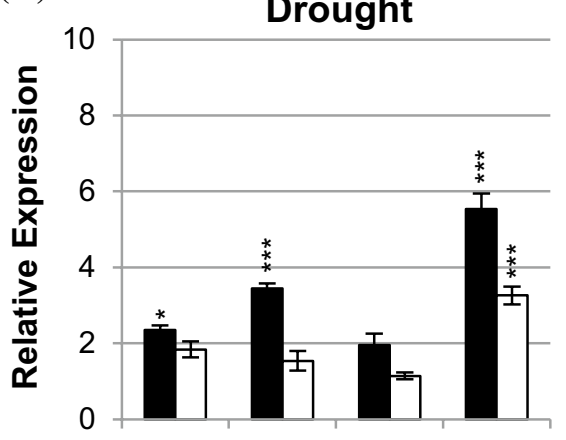

$15 \min \square 1 \mathrm{~h}$
(B)

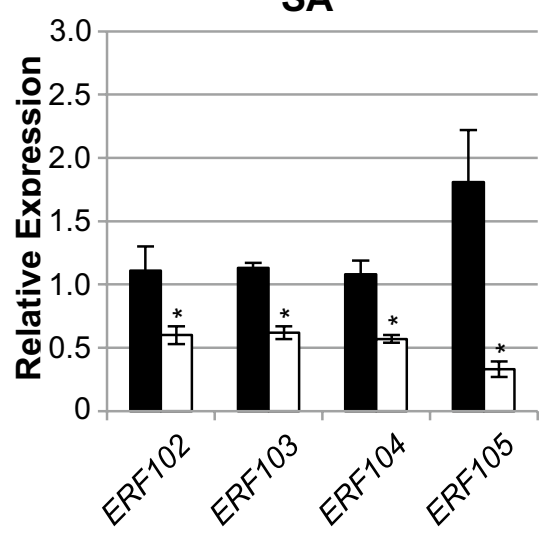

- $30 \min \square 2 \mathrm{~h}$

(E)
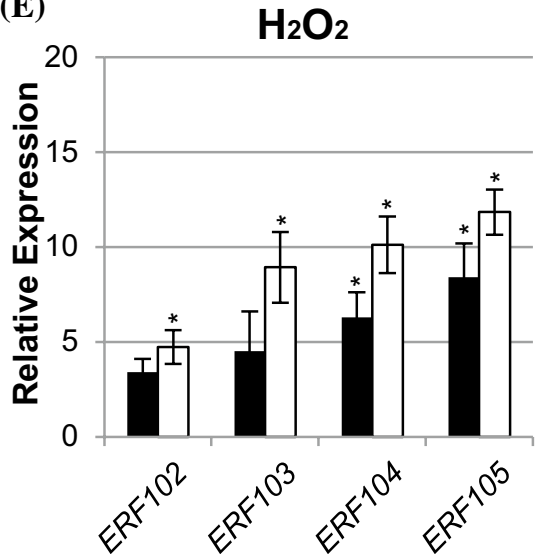

- $15 \min \square 2 \mathrm{~h}$

(H)

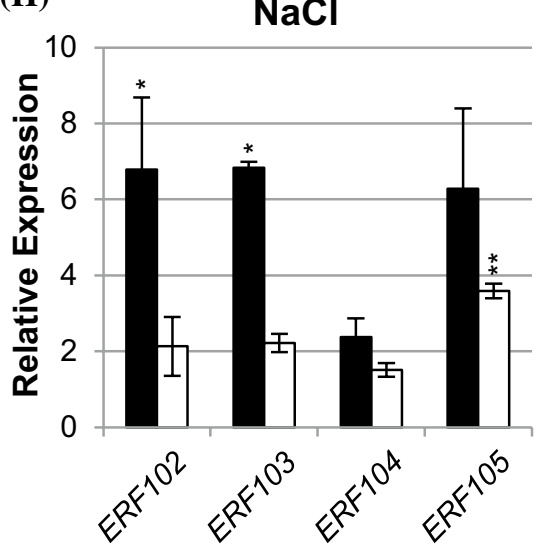

- $15 \min \square 2 \mathrm{~h}$
(C)

$42{ }^{\circ} \mathrm{C}$

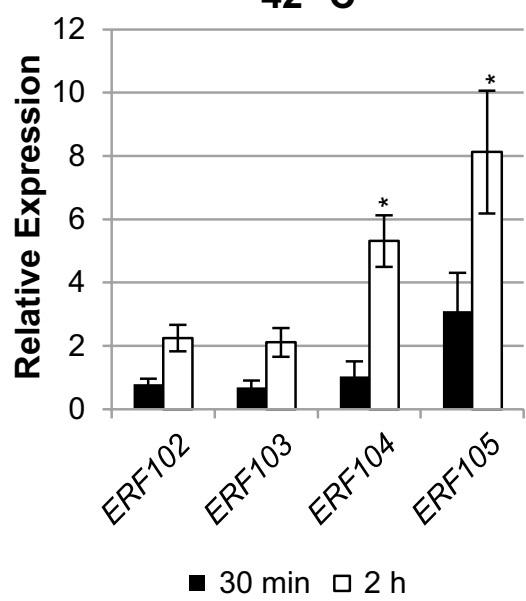

(F)

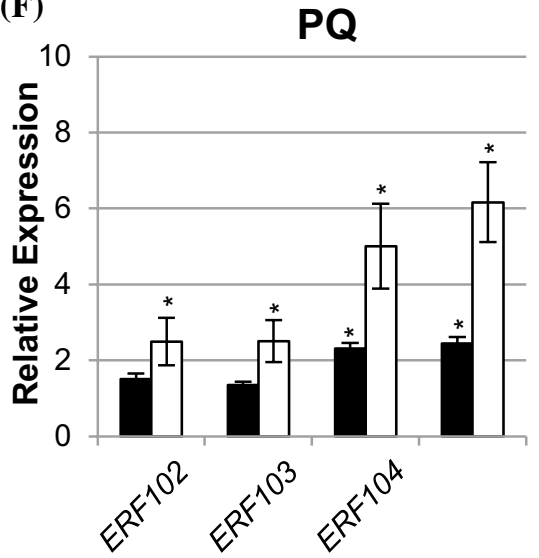

- $30 \min \square 2 \mathrm{~h}$

(I)

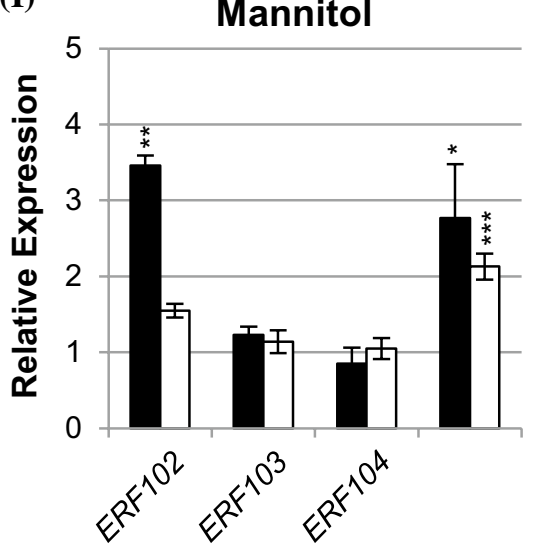

$15 \min \square 2 \mathrm{~h}$
Fig. 2 Regulation of ERF102 to ERF105 gene expression. Relative expression of ERF102 to ERF105 in eleven-day-old wild-type seedlings (eight pooled seedlings per sample) after hormone or stress treatment. a Auxin $(10 \mu \mathrm{M}$ NAA), b salicylic acid $(10 \mathrm{mM}$ $\mathrm{SA})$, $\mathbf{c}$ heat $\left(42{ }^{\circ} \mathrm{C}\right)$, d high light $\left(1000 \mu \mathrm{mol} \mathrm{m} \mathrm{m}^{-2} \mathrm{~s}^{-1}\right)$, e and $\mathbf{f}$ oxidative stress (e; $500 \mathrm{mM} \mathrm{H} 2 \mathrm{O} 2, \mathbf{f} ; 30 \mu \mathrm{M}$ paraquat), $\mathbf{g}$ drought, $\mathbf{h}$ salt (200 mM NaCl) and $\mathbf{i}$ osmotic stress (200 mM mannitol). Transcript levels of wild-type samples under control conditions were set to $1(n \geq 4)$. Asterisks indicate significant differences to the respective mock treatment $(* \mathrm{p}<0.05 ; * * \mathrm{p}<0.01$; $* * * \mathrm{p}<0.001)$. Error bars represent SE 
distribution of a selection of these CAREs along the promoters of the four $E R F$ genes revealing distinct patterns despite the often similar transcriptional responses to hormones and stress treatments.

Taken together, the four $E R F$ genes showed similar, very rapid and often transient transcriptional responses to different plant hormones, including an extraordinarily strong induction by auxin, as well as rapid, strong and often comparable responses to different stress treatments. Some individual response profiles such as stronger responses to heat by ERF104 and ERF 105 or the lack of response to $\mathrm{NaCl}$ and mannitol by ERF 104 were observed as well. These partly similar stress response profiles would be consistent with overlapping functions in response to these stresses.

\section{pERF102:GUS to pERF105:GUS reporter genes are expressed in different tissues in Arabidopsis thaliana}

Transgenic plants expressing the GUS reporter gene under the control of $\sim 2 \mathrm{~kb}$ of the ERF102 to ERF 104 promoters located $5^{\prime}$ upstream of the coding regions were analysed to determine the tissue-specific expression of these genes.

Thirty h after imbibition, strong GUS activity of pERF 102:GUS plants was detected in the root tip transition zone of germinated seedlings (Fig. 3a) and expanded within the next $30 \mathrm{~h}$ within the radicle (Fig. 3b). Ten DAG, pERF 102:GUS was expressed in all root tissues except root tips and root hairs. The strongest GUS activity was observed in the vascular bundle of primary roots and in cortex cells that surround emerging lateral roots (Fig. 3c-e). Weak pERF 102:GUS expression was detected in the shoot apical meristem (SAM) of seedlings (Fig. 3f).

pERF 103:GUS activity was detected $60 \mathrm{~h}$ after imbibition in the root tip (Fig. 3g) and seven DAG in the whole root (Fig. 3h). Very high activity was detected in the root apical meristem (RAM) (Fig. 3j). pERF103:GUS was also expressed in the root tip of lateral roots, but only after stage VIII of lateral root development (Péret et al. 2009) (Fig. 3k). GUS activity was observed in the vasculature of primary roots (Fig. 31), but not in the vasculature of emerging or fully developed lateral roots, and in cortex cells that surround emerging lateral roots (Fig. $3 \mathrm{~m}$ ). In shoot tissues, weak expression of $p E R F 103: G U S$ was detected only in the shoot apex (Fig. 3i).

pERF 104:GUS expression was also detected early after germination. Sixty h after imbibition, $p E R F 104: G U S$ was weakly expressed in the vasculature of hypocotyls and cotyledons and slightly stronger in the vasculature of radicles (Fig. 3n). Seven-day-old seedlings showed GUS activity in the vascular tissues as well as in the shoot apex (Fig. 3o-q). A particularly well-defined local GUS signal was noted in the quiescent center of roots (Fig. 3r, s). In addition, GUS activity was detected in the style of the gynoecium and at the base and in the apex of siliques (Fig. 3t, u).

As plants matured, GUS activity of $p E R F 102: G U S$ to pERF 104:GUS plants was present in the same tissues as in young seedlings but declined progressively (data not shown). Together, promoter:GUS fusions of all three $E R F$ genes were predominantly expressed in root tissues, similar to $p E R F 105: G U S$ (Bolt et al. 2017).

\section{GFP-ERF102 to GFP-ERF105 are located in the nucleus}

To examine the subcellular localisation of the ERF102 to ERF104 proteins, full-length cDNAs of ERF102 to ERF104 were fused in frame to the $3^{\prime}$ end of the GREEN FLUORESCENT PROTEIN (GFP) coding sequence. The resulting GFP-ERF 102, GFP-ERF 103 and GFP-ERF 104 fusion genes driven by the cauliflower mosaic virus (CaMV) $35 \mathrm{~S}$ promoter were transiently expressed in Nicotiana benthamiana leaf cells. Confocal imaging of GFP fluorescence in leaf cells showed that all three fusion proteins were predominantly located in the nucleus, weaker signals were derived from the cytosol (Fig. 4). This pattern was similar to the predominant nuclear localisation of GFP-ERF105 (Bolt et al. 2017).

\section{Characterisation of plants with altered ERF102 to ERF105 expression levels}

To identify and compare biological functions of the ERF102 to ERF104 genes, we studied transgenic lines with altered expression levels. For ERF102, a homozygous T-DNA insertion line (erf102; SAIL_46_C02) was obtained. Verification of the annotated location of the T-DNA insertion in erf102 by sequencing revealed that the T-DNA is located at position +507 within the AP2/ERF domain (Fig. S2a). RT-PCR analysis did not detect any expression of ERF102 in erf102 plants, suggesting that it is a null allele (Fig. S2b). The morphological phenotype of the erf102 mutant described below (Fig. S3e) was fully complemented by introgression of the 35S:ERF102 gene (Fig. S2c-S2f). In several available T-DNA insertion lines for ERF103 (SALK_087356, GABI_085B06) or ERF104 (SALK_024275, SALK_057720, SALK_152806) we detected residual $E R F$ expression. Therefore, lines with a reduced ERF103 or ERF104 expression were constructed using artificial microRNAs (amiRNAs) (Schwab et al. 2006). Two independent, homozygous amiRNA expressing lines with the lowest residual expression of the target genes were selected for further experiments (Fig. S3a and Bolt et al. 2017). Moreover, lines overexpressing ERF102 to ERF104 under control of the CaMV $35 S$ promoter were 
Fig. 3 Expression of the GUS reporter gene under control of the ERF102, ERF103 and ERF104 promoters. Histochemical localisation of GUS activity in Arabidopsis pERF:GUS reporter lines. $p E R F 102: G U S$ seedlings $30 \mathrm{~h}$ (a) and $60 \mathrm{~h}$ (b) after imbibition of seeds and ten DAG (c-f). a, b Germinating seeds, $\mathbf{c}$ whole seedling, $\mathbf{d}$ and e primary root with emerging lateral roots and $\mathbf{f}$ shoot apex with a stained apical meristem. pERF103:GUS seedlings $60 \mathrm{~h}$ (g) after imbibition of seeds and seven DAG (h-m). g Germinating seeds, $\mathbf{h}$ whole seedling, i shoot apex with stained shoot apical meristem, $\mathbf{j}$ tip of primary root, $\mathbf{k}$ lateral root, $\mathbf{l}$ vasculature of primary root, m primary root with emerging lateral root. $p E R F 104: G U S$ seedlings $60 \mathrm{~h}(\mathbf{n})$ after imbibition of seeds, seven $(\mathbf{o}-\mathbf{s})$ and 21 DAG (t, u). n Germinating seeds, $\mathbf{o}$ whole seedling, $\mathbf{p}$ vasculature of primary root, $\mathbf{q}$ shoot apex, (inset shows stained quiescent center cells), $\mathbf{r}$ tip of primary root, $\mathbf{s}$ primary root with emerging lateral root, $\mathbf{t}$ apical part of gynoecium with stained style and $\mathbf{u}$ inflorescence with flowers and young siliques. Scale bars $=100 \mu \mathrm{m}$ in $\mathbf{a}, \mathbf{d}, \mathbf{e}$, $\mathbf{i}-\mathbf{m}, \mathbf{p}, \mathbf{q}$, and $\mathbf{u} ; 400 \mu \mathrm{m}$ in $\mathbf{b}$ and $\mathbf{n} ; 1 \mathrm{~mm}$ in $\mathbf{c} ; 50 \mu \mathrm{m}$ in $\mathbf{f}, \mathbf{r}$ and $\mathbf{s} ; 200 \mu \mathrm{m}$ in $\mathbf{g} ; 2 \mathrm{~mm}$ in $\mathbf{h}$, $\mathbf{o}$ and $\mathbf{t}$
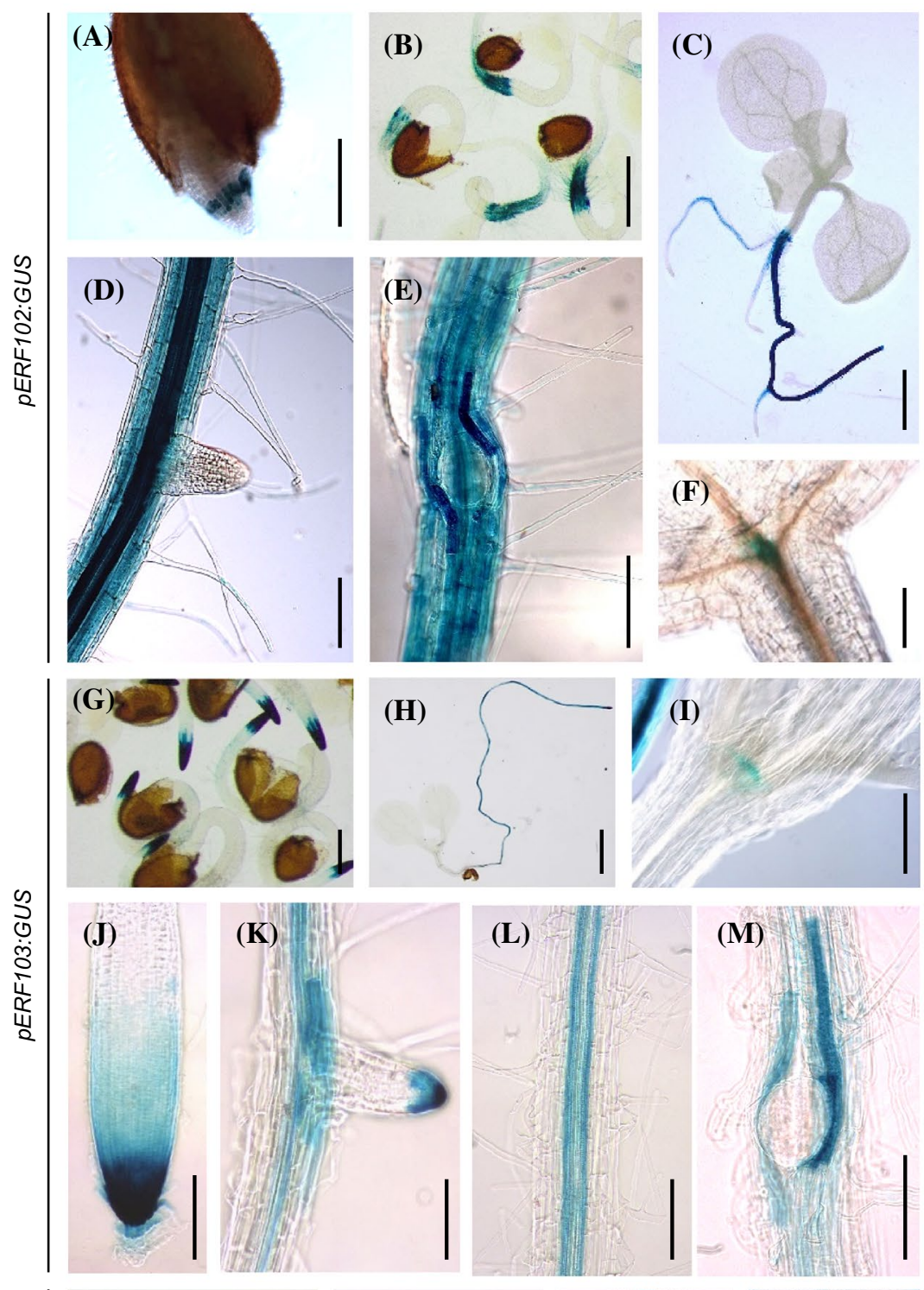

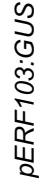
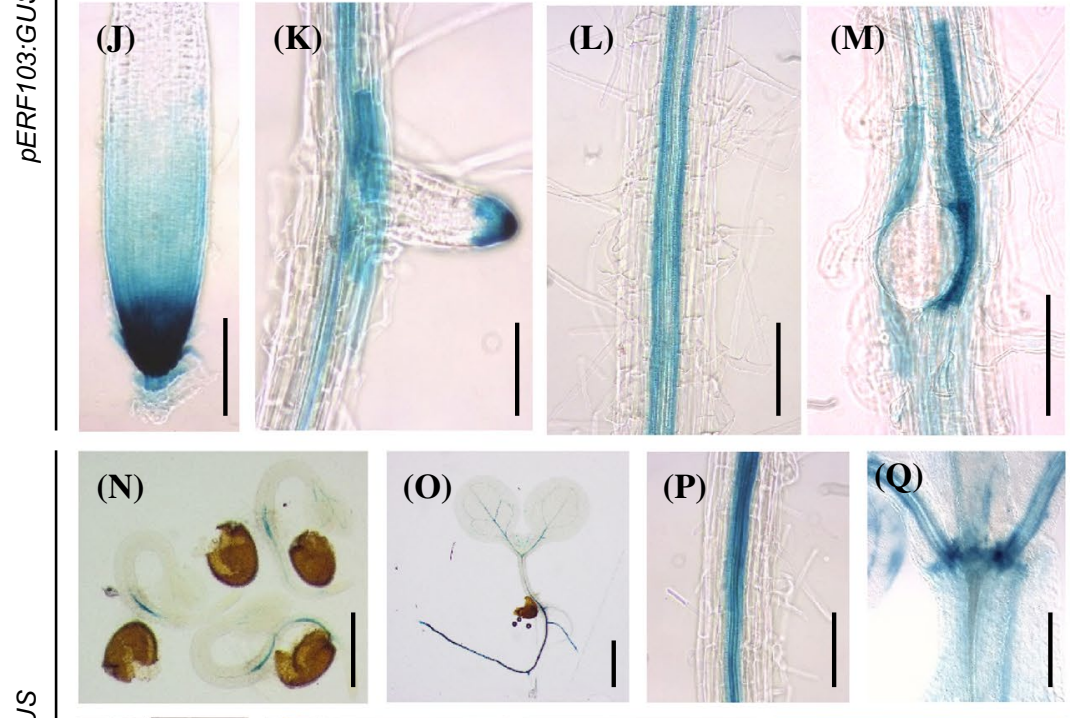

0
0
$\dot{\square}$
$\frac{0}{4}$
$\frac{1}{\frac{1}{u}}$
$\frac{1}{2}$
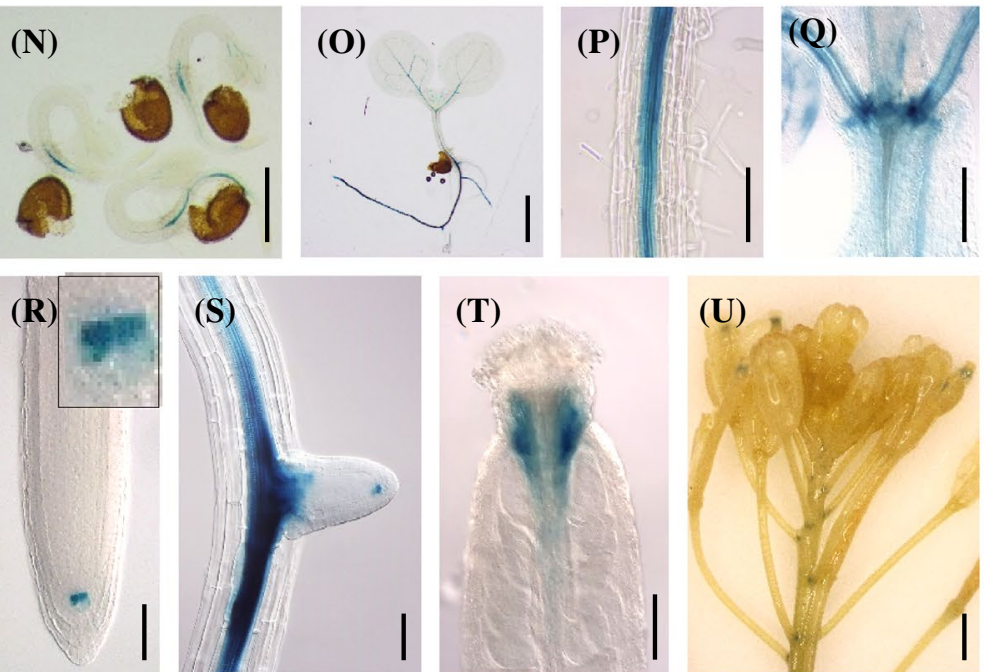

(T)

(U)
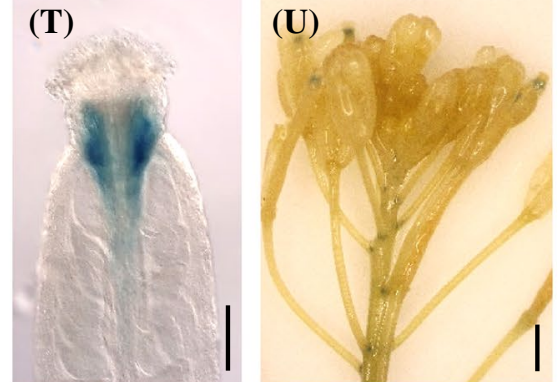
(A)
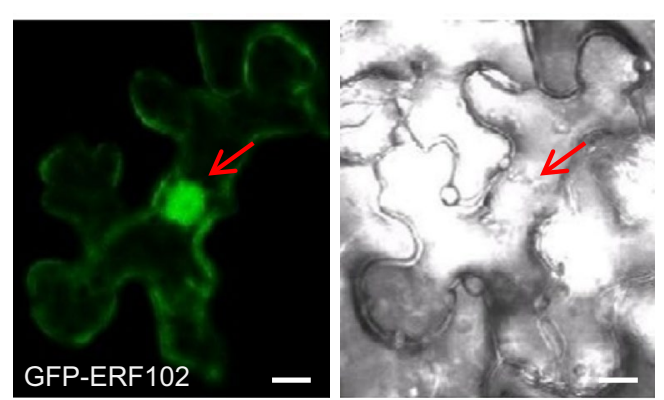

(C)
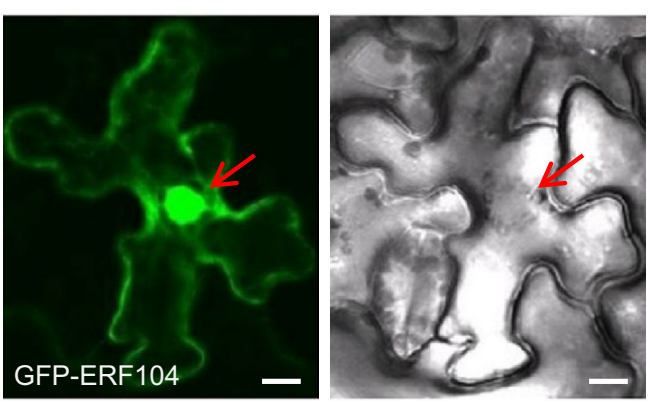

Fig. 4 Subcellular localisation of GFP-ERF102, GFP-ERF103 and GFP-ERF104 fusion proteins. Transient expression of (a) $35 \mathrm{~S}: \mathrm{GFP}$ ERF102, (b) 35S:GFP-ERF103 and (c) 35S:GFP-ERF104 in leaf

constructed and two strongly expressing lines selected (Fig. $\mathrm{S} 3 \mathrm{~b}-\mathrm{d})$.

Morphological analysis of plants with reduced or increased ERF102 to ERF104 expression revealed in most cases only slight differences of shoot growth compared to wild-type plants. Furthermore, plants with altered expression of ERF102, ERF103 or ERF104 flowered at the same time as wild-type plants and showed a similar onset of leaf senescence (data not shown). In contrast, root elongation, the formation of lateral roots as well as the lateral root density was more strongly affected by altered expression of these genes (Fig. $5 \mathrm{c}-\mathrm{e}$ ).

The erf 102 mutant exhibited an about $10 \%$ reduced shoot height compared to the wild type. Overexpressing lines of ERF102 exhibited a slightly but not significantly increased shoot height as well as a 10\% (ERF102ox-1) and 8\% (ERF102ox-2) bigger rosette diameter (Fig. 5a, b). Moreover, ten DAG erf102 exhibited 13\% lower and ERF102ox lines 13\% higher primary root elongation (Fig. 5c). erf102 showed 27\% less and ERF102ox-1 and ERF102ox-2 48\% and $51 \%$ more lateral roots compared to wild type (Fig. $5 \mathrm{~d}$ ). Lateral root density was increased $29-31 \%$ in the ERF102ox lines (Fig. 5e).

Both 35S:ami103 lines were smaller in size, with an $8 \%$ reduced shoot height and a 6-9\% reduced rosette diameter compared to the wild type, while ERF103 overexpression did not cause phenotypic differences in shoot height and

(B)

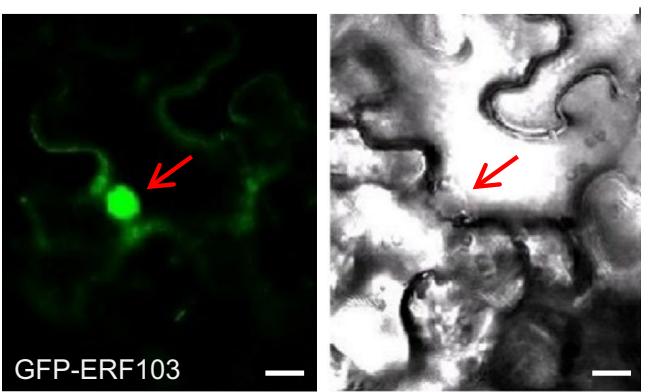

epidermis cells of $N$. benthamiana was analysed by confocal laser scanning microscopy. Left, fluorescence of GFP; right, bright field picture. The red arrows indicate the nucleus. Scale bars $=10 \mu \mathrm{m}$

rosette size (Fig. 5a, b). Primary root elongation was about 13\% lower in both 35S:ami103 lines whereas ERF103ox-1 and ERF103ox-2 exhibited $12 \%$ and $17 \%$ longer primary roots compared to wild type (Fig. 5c). Similarly, 35S:ami 103 lines had up to $32 \%$ less and ERF103ox plants up to $31 \%$ more lateral roots than wild type (Fig. 5d).

35S:ami104 lines had a 9\% (35S:ami104-1) and 18\% (35S:ami104-2) reduced shoot height, but an unchanged rosette diameter (Fig. 5a, b). Primary root elongation of 35S:ami104 lines was about $13 \%$ slightly reduced and enhanced by up to $29 \%$ in ERF 104 overexpressing lines (Fig. 5c). The number of lateral roots was reduced by about $20 \%$ in both 35S:ami104 lines, while ERF104ox-1 and ERF104ox-2 exhibited 57\% and 53\% more lateral roots (Fig. 5d) and had a 30\% and 22\% higher lateral root density compared to wild type (Fig. 5e).

Bolt et al. (2017) described that the shoot phenotype of erf105 and ERF105ox lines resembled the wild type. Here, root analysis revealed a $14 \%$ lower primary root elongation (Fig. 5c) and 23\% less lateral roots in erf 105 compared to wild type (Fig. 5c). ERF105ox lines showed a 17-25\% higher primary root elongation, $53-83 \%$ more lateral roots and a $31-44 \%$ higher lateral root density compared to wild type (Fig. 5c-e).

To examine a potentially redundant role of the four $E R F$ genes, several higher order mutants were generated, namely erf102 35S:amiERF103, erf102 35S:amiERF104, 
(A)

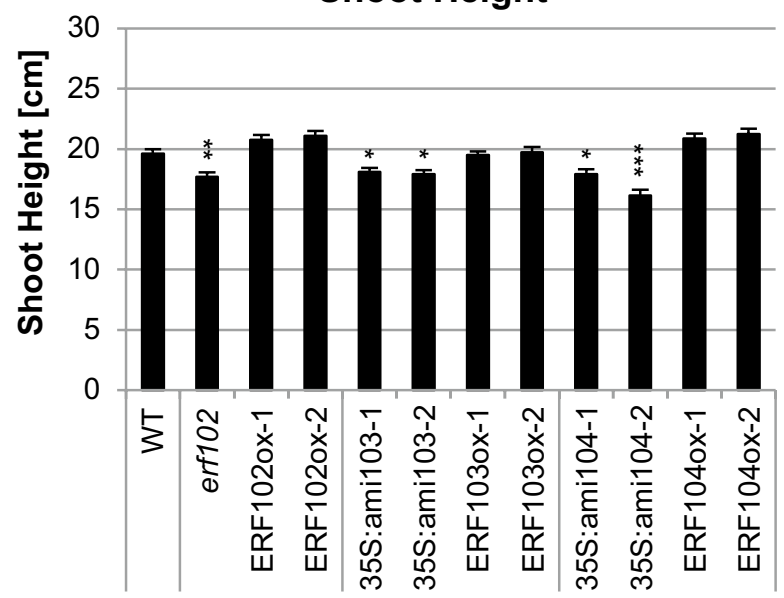

(C)

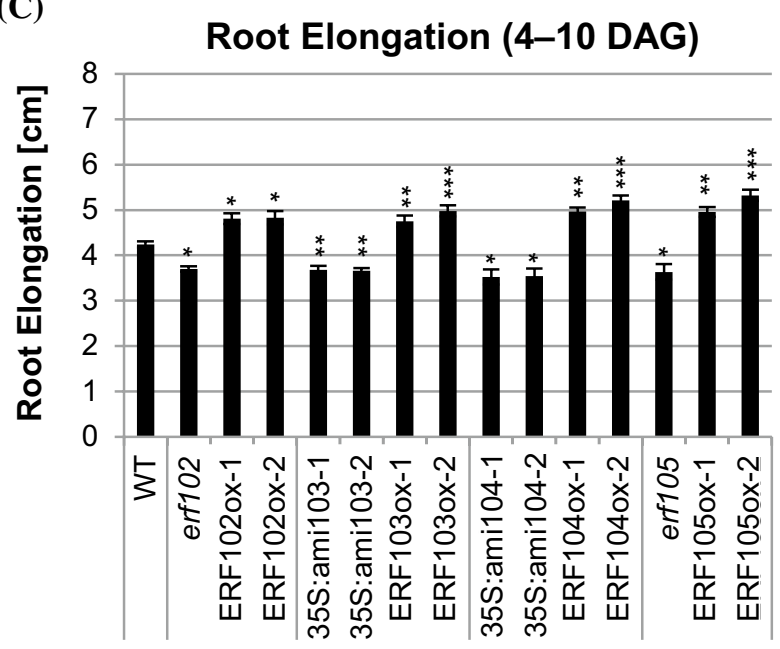

(E)

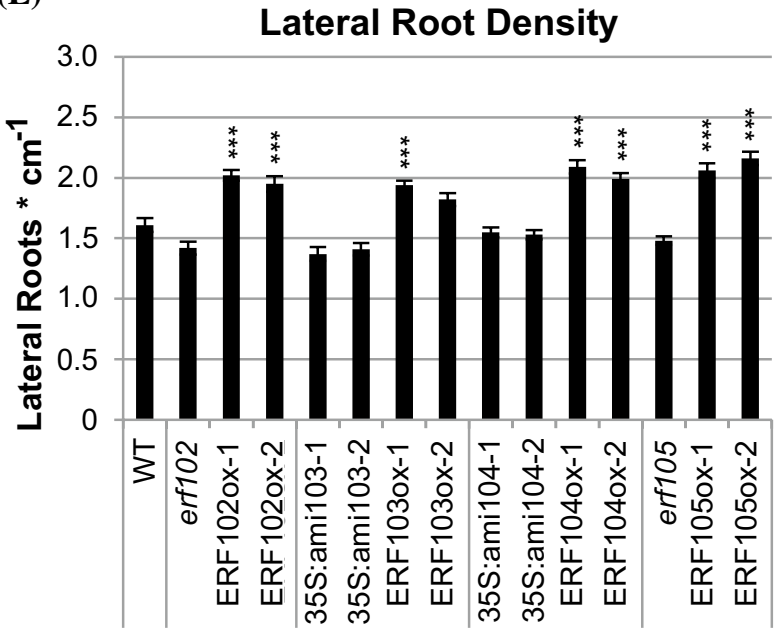

(B)

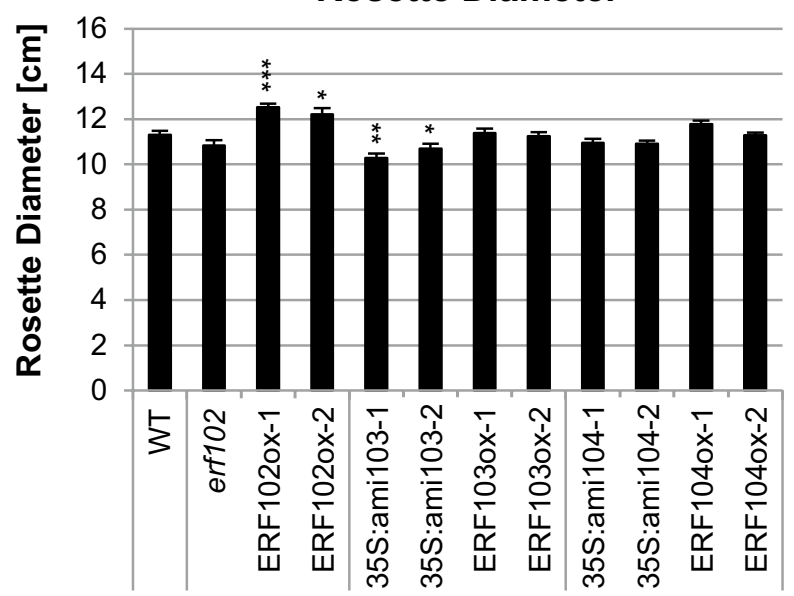

(D)

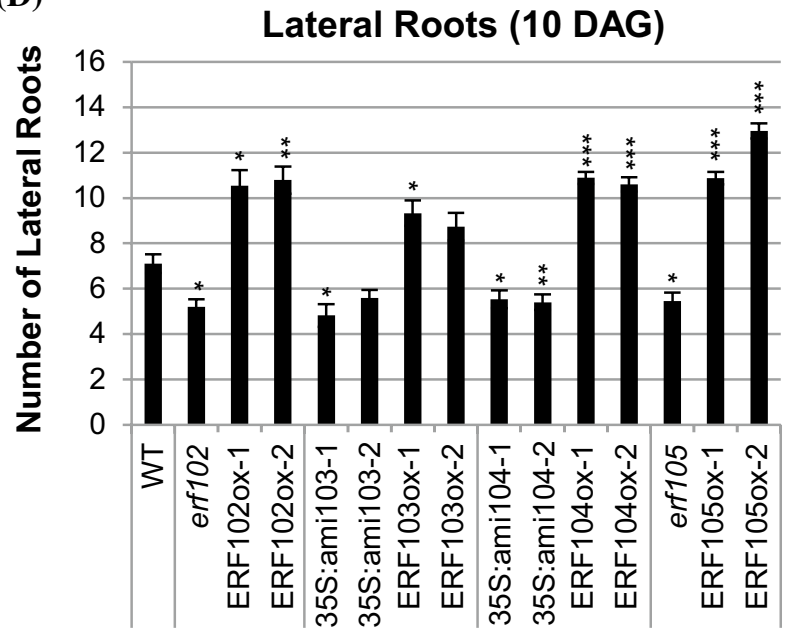


4 Fig. 5 Shoot and root growth of lines with altered ERF102 to ERF105 expression levels. Shoot height (a) and rosette diameter (b) of 35-day-old plants grown on soil. (c) Elongation of the primary root determined between four and ten DAG (c), number of lateral roots (d) and lateral root density (e) determined ten DAG of plants grown on half-strength MS medium. Asterisks indicate significant differences to the wild type $(\mathrm{n} \geq 30),\left({ }^{*} \mathrm{p}<0.05 ; * * \mathrm{p}<0.01 ; * * * \mathrm{p}<0.001\right)$. Error bars represent $\mathrm{SE}$

erf105 35S:amiERF103, and erf102 35S:amiERF104/105. These lines include all possible combinations of at least two $E R F$ genes that are mutated or have a lowered expression, except combined loss of function of ERF103 and ERF104. Higher order mutants did not show a phenotypic additive effect compared to the respective single mutants with respect to rosette diameter, shoot height, primary root elongation, number of lateral roots and flowering time (data not shown). These results suggest that ERF102 to ERF105 are not acting redundantly on growth regulation. However, we cannot exclude that the degree of downregulation achieved by amiRNAs is insufficient to uncover redundant gene activities.

\section{Analysis of the functions of the ERF102 to ERF105 genes in the cold acclimation response}

ERF105 is a positive regulator of Arabidopsis freezing tolerance and cold acclimation (Bolt et al. 2017). Therefore, we analysed whether the ERF102 to ERF104 genes, which are also regulated by cold (Lee et al. 2005; Vogel et al. 2005; Park et al. 2015; Bolt et al. 2017), also play a role in regulating freezing tolerance and cold acclimation. To this end, we studied the transcript accumulation of selected cold responsive genes in $E R F$ single and double mutants and analysed the freezing tolerance of these mutants.

First, we examined the expression levels of selected coldresponsive genes in plants with reduced or enhanced expression of a single ERF102 to ERF104 gene before (non-acclimated, NA) and after 14 days of cold acclimation (ACC14) and compared these to wild type. The transcript levels of cold-responsive genes were in all lines similar to wild type (Fig. S4), which contrasts with the strongly altered transcript levels displayed by the erf105 mutant and ERF 105 overexpressing lines (Bolt et al. 2017).

The analysis of higher order mutants revealed that under non-acclimated (NA) conditions the steady state mRNA levels of $C B F 1, C B F 2, C O R 15 A$, and COR15B were up to $60 \%$ lower in the erf105 35S:ami103-1 plants compared to those of the wild type (Fig. 6). In all other mutant combinations the basic expression level of these cold-responsive genes was slightly, but not significantly lower than in the wild type. After 14 days of acclimation at $4{ }^{\circ} \mathrm{C}$ (ACC14), the expression levels of these genes were elevated between two- and five-fold in wild type compared to NA plants.
ACC14 plants with mutated ERF102 or ERF105 genes combined with reduced expression of ERF 103 or ERF104 showed, in most cases, a lower induction of the cold-responsive genes. For example, the induction levels of $C B F 2$ and $C O R 15 B$ were reduced in all hybrid lines to about $50 \%$ of the wild-type level. Strikingly, the induction of $C F B 3$ was completely absent in all mutant lines while it was induced about twofold in wild type. In contrast, ZAT12 gene expression showed a stronger increase in erf102 35S:ami103-1, erf102 35S:ami104-2 and erf105 35S:ami103-1 than in wild type (Fig. 6f).

Next, we determined the freezing tolerance of plants with reduced ERF102, ERF103 and ERF104 gene expression before and after 14 day of cold acclimation at $4{ }^{\circ} \mathrm{C}$ by an electrolyte leakage assay of detached leaves (Rohde et al. 2004; Thalhammer et al. 2014). To take into account the almost complete arrest of plant growth at $4{ }^{\circ} \mathrm{C}$, the electrolyte leakage assay was performed at the same developmental state for both NA and ACC plants. erf 105 mutant plants used as positive control showed higher $\mathrm{LT}_{50}$ (temperature of $50 \%$ electrolyte leakage) values $\left(-3.99 \pm 0.13{ }^{\circ} \mathrm{C}\right.$ in NA plants and $-8.99 \pm 0.17{ }^{\circ} \mathrm{C}$ in $\mathrm{ACC} 14$ plants) compared to wild type $\left(-4.7 \pm 0.11{ }^{\circ} \mathrm{C}\right.$ in NA plants and $-10.82 \pm 0.12{ }^{\circ} \mathrm{C}$ in ACC14 plants) (Fig. 7a), which is consistent with previous results (Bolt et al. 2017). In contrast, erf102, 35S:ami103-1 and 35S:ami104-2 plants did not show differences in $\mathrm{LT}_{50}$ values compared to wild type. Also, overexpression of single ERF102, ERF103 or ERF104 genes did not lead to altered freezing tolerance under NA conditions (Fig. S5). The behavior of the overexpressing lines in response to acclimation was not tested.

Analysis of the freezing tolerance of higher order mutants revealed that only the erf105 35S:ami103-1 plants showed higher $\mathrm{LT}_{50}$ values $\left(-4.93 \pm 0.12{ }^{\circ} \mathrm{C}\right)$ compared to wild type $\left(-5.46 \pm 0.12{ }^{\circ} \mathrm{C}\right)$ under NA conditions (Fig. $\left.7 b\right)$. Following cold acclimation, several combinations exhibited higher $\mathrm{LT}_{50}$ values compared to wild type $\left(-9.54 \pm 0.18^{\circ} \mathrm{C}\right)$. The strongest change was shown by erf102 35S:ami103-1 $\left(-7.89 \pm 0.24{ }^{\circ} \mathrm{C}\right)$, while erf105 35S:ami103-1 $\left(-8.78 \pm 0.25^{\circ} \mathrm{C}\right)$ as well as erf102 35S:ami104/105-1 $\left(-8.79 \pm 0.25{ }^{\circ} \mathrm{C}\right)$ showed smaller effects. In contrast, erf102 35S:ami104-2 showed a similar $\mathrm{LT}_{50}$ as wild type after cold acclimation (Fig. 7b).

\section{Discussion}

Recently, we reported that ERF102 to ERF105 are regulated by cold and different cold stress-related hormones, and we demonstrated that ERF105 has a function in the freezing tolerance and cold acclimation of Arabidopsis (Bolt et al. 2017). In the present study we significantly extended this work and first investigated further expression characteristics 

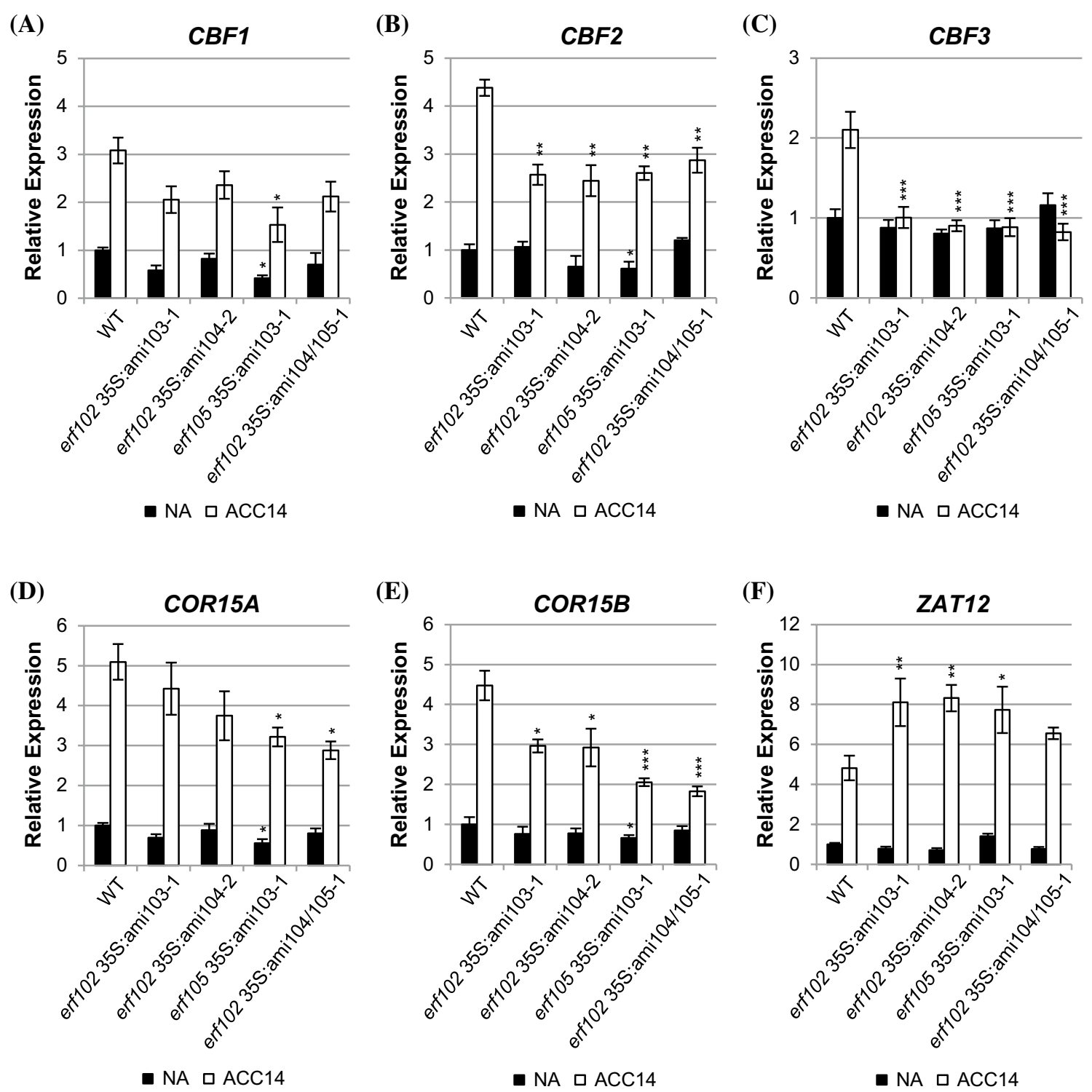

Fig. 6 Expression of selected cold-responsive genes in lines with reduced $E R F 102$ to $E R F 105$ expression. Relative expression of $C B F 1$ (a), CBF2 (b), CBF3 (c), COR15A (d), COR15B (e) and ZAT12 (f) genes in six-week-old lines with reduced ERF102 to ERF105 expression before (non-acclimated, NA) and after 14 days (acclimated,
ACC14) of cold acclimation at $4{ }^{\circ} \mathrm{C}$. Transcript levels of wild-type samples under non-acclimated conditions were set to $1(n \geq 4)$. Asterisks indicate significant differences to the respective wild-type condition $(* \mathrm{p}<0.05 ; * * \mathrm{p}<0.01 ; * * \mathrm{p}<0.001)$. Error bars represent SE

partial functional redundancy of ERF102 to ERF105. For instance, all genes were rapidly downregulated by SA (Fig. 2b) and upregulated by high light or $\mathrm{H}_{2} \mathrm{O}_{2}$ (Fig. 2e, f). Network analysis of publicly available transcriptome data using for instance GeneMANIA (Warde-Farley et al. 2010) also showed that these four $E R F$ genes are co-regulated and co-expressed in a large number of conditions including numerous hormone and chemical treatments (Fig. S6). However, some individual response profiles were discovered as well. Thus, not all four ERF genes 
(A)

$$
\text { Electrolyte Leakage }
$$

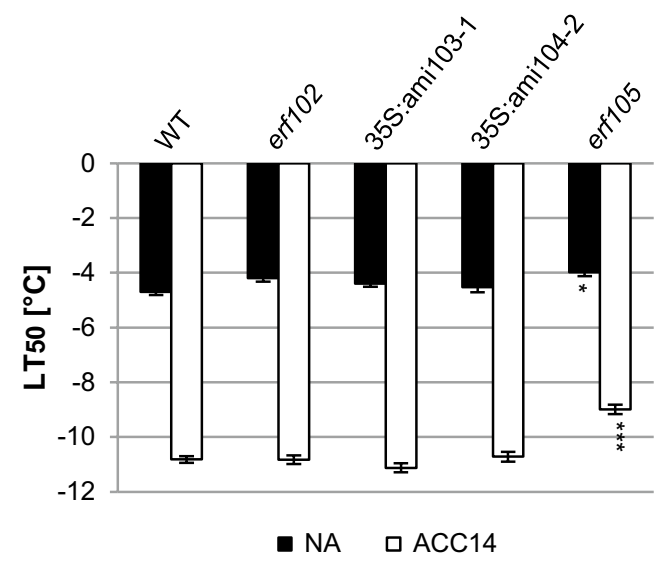

Fig. 7 Electrolyte leakage assays of lines with reduced ERF102 to ERF105 expression. Electrolyte leakage assays on detached leaves of lines with mutations or reduced expression affecting single $E R F$ genes (a) or several ERF genes (b) before (non-acclimated, NA) and after 14 days (acclimated, ACC14) of cold acclimation at $4{ }^{\circ} \mathrm{C}$. The

were transcriptionally regulated by heat, drought, $\mathrm{NaCl}$, or mannitol (Fig. 2). Together, the analysis of transcriptional regulation and the occurrence of cis-acting promoter sequences is in line with the idea that ERF102 to ERF105 have roles in multiple hormone and stress responses as was shown for these and other ERFs in a number of cases (Bethke et al. 2009; Moffat et al. 2012; Son et al. 2012; Dubois et al. 2013; reviewed by Licausi et al. 2013; Mase et al. 2013; Meng et al. 2013; Sewelam et al. 2013; Moore et al. 2014a, b; Vogel et al. 2014; Dubois et al. 2015; Xie et al. 2019).

\section{The ERF102 to ERF105 genes have a limited impact on plant growth}

The tissue-specific expression patterns of $p E R F 102: G U S$ to $p E R F 105: G U S$ are partly overlapping, which is in accordance with a redundant function of the ERF proteins. All four genes are predominantly expressed in the root, only for pERF 105:GUS a significant expression was detected also in several shoot tissues such as vasculature, apical shoot and stomata (Bolt et al. 2017). Expression of all four $p E R F-G U S$ reporter genes was visible shortly after germination in different cell types of the radicle and later in distinct root tissues and cell types. For example, $p E R F 102: G U S, p E R F 103: G U S$ and $p E R F 105: G U S$ were expressed in the cortex cells that surround emerging lateral roots. Interestingly, expression of ERF102, ERF103 and ERF105 is regulated by cytokinin and auxin, two key hormones of lateral root development (Benková et al. 2003; Casimiro et al. 2003; Swarup et al. 2008;

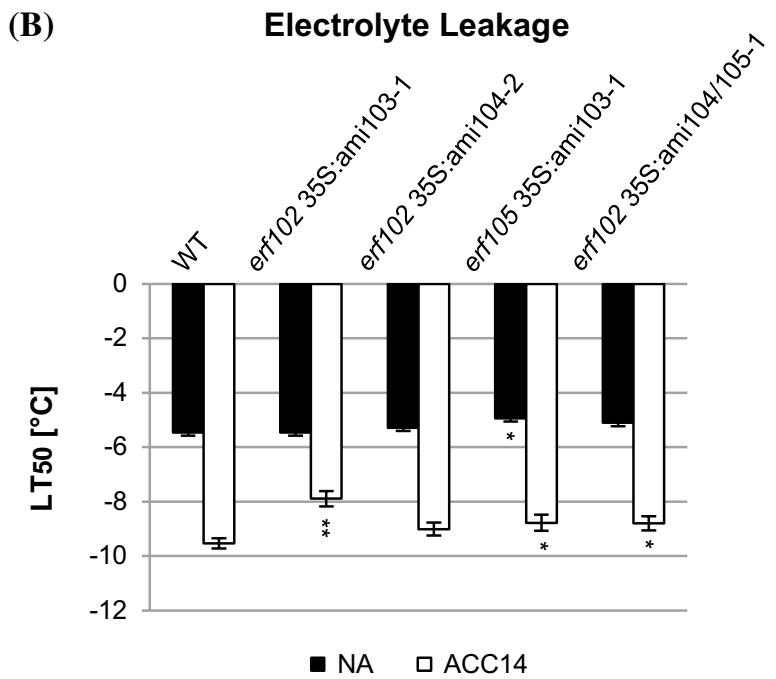

bars represent the means $\pm \mathrm{SE}$ from four replicate measurements where each replicate comprised leaves from three plants. Asterisks indicate significant differences to the wild type $(* \mathrm{p}<0.05 ; * * \mathrm{p}<0.01$; $* * * \mathrm{p}<0.001)$

Chang et al. 2013, 2015). Insertional mutants and amiRNA lines indicated a role of these genes in regulating root elongation. All mutants (erf102, erf105) as well as 35S:ami103 and 35S:ami104 lines had about $10-15 \%$ shorter roots and all overexpressing showed a ca. $20 \%$ increased root elongation (Fig. 5c). Most loss-of-function mutants formed also less lateral roots. However, the differences were small and the lateral root density mostly not significantly altered (Fig. 5d-e). Opposite and stronger phenotypic changes were noted in the respective overexpressing lines, which had an increased number (by up to $~ 85 \%$ ) of lateral roots and a higher lateral root density. Although overexpression experiments may produce artefacts and are not fully conclusive they have been often informative about the functional context of a given gene. Loss-of-function phenotypes of genes regulating root architecture can be subtle or depend on the environmental or developmental context (Motte et al. 2019) and thus might have gone unnoticed in the erf mutants. The strong regulation of the four $E R F$ genes by different stressors suggests that they might be particularly relevant under stressful conditions. It cannot be excluded that members of the ERF105 gene subfamily studied here contribute to regulating root architecture under specific environmental conditions, this requires further investigation.

Among the expression sites of the four $E R F$ genes, the expression of $p E R F 104: G U S$ in the quiescent center (Fig. 3r) particularly intriguing. Noteworthy, among the direct targets of ERF104 is the transcription factor gene SCARECROW (SCR) (Sparks et al. 2016). SCR is, together with SHORTROOT, essential for quiescent center specification and maintenance 
(reviewed by Benfey 2016; Salvi et al. 2018). Further, in a yeast two-hybrid screen the transcription factor MYB56/ BRASSINOSTEROIDS AT VASCULAR AND ORGANIZING CENTER (BRAVO) was identified as an interactor of ERF104 (our unpublished result). MYB56/BRAVO represses cell divisions in the quiescent center thus counteracting SCR (Di Laurenzio et al. 1996; Vilarrasa-Blasi et al. 2014). It is known that interaction with other transcription factors modulates the activity of ERFs (Licausi et al. 2013; Xie et al. 2019). While these data suggest that ERF104 might be part of the transcription factor network in the quiescent center, we have been unable to detect any changes of cellular organisation in the quiescent center and surrounding cells nor did we detect altered SCR gene expression in the 35S:ami104 and ERF104ox lines (data not shown). It could be that the decrease in ERF104 expression obtained in the amiRNA lines is not sufficient to cause a strong loss-of-function phenotype, analysis of a null mutation could be more informative.

\section{The ERF102 to ERF105 genes regulate the response to cold stress}

One important goal of this work was to analyse the possible roles of the ERF105-related transcription factors in the response to cold stress. ERF102 to ERF105 are rapidly cold-induced (Bolt et al. 2017) in parallel with the first wave transcription factors of the cold stress response including the $C B F$ genes (Park et al. 2015). Mutation or reduced expression of ERF102, ERF103 or ERF104 single genes did not lead to an altered freezing tolerance. In case of the amiRNA lines this could be due to residual gene expression (Figs. 7a and S1). Thus, among the four genes only the mutation of ERF105 resulted in a decreased freezing tolerance before and after cold acclimation compared to wild type underpinning its primary role (Fig. 7a and Bolt et al. 2017). However, the analysis of freezing tolerance of higher order mutants indicated that ERF102 and ERF103 also play a role in cold acclimation, since the reduced expression of both genes resulted in altered expression of cold response genes (Fig. 6) and higher freezing sensitivity (Fig. 7b). The eventual role of ERF104 cannot be determined with certainty as only amiRNA lines were available and not all combinations with other $E R F$ genes were tested. 35S:ami104 lines in combination with the erf102 mutation showed an altered expression of cold-responsive genes similar to other double mutant combinations (Fig. 6) and the $\mathrm{LT}_{50}$ value was higher than in wild type although the significance was below the threshold ( $p<0.05$ ), indicating that ERF104 might be involved in the response to cold as well. Our attempts to demonstrate a role of these $E R F$ genes at low temperatures in the root as was reported for $C R F 2$ and $C R F 3$ belonging to a different class of $E R F$ genes (Jeon et al. 2016), have failed. Such an activity could, as was stated above, be masked by incomplete loss of function and/or the unknown nature of their specific activities.

Based on transcript data which show a lowered activation of $C B F$ and $C O R$ genes in erf gene mutants after cold acclimation (Fig. 6), ERF102, ERF103 and ERF104 may also play a role upstream of these genes as was suggested for ERF105 (Bolt et al. 2017). Increased CBF3 expression upon cold acclimation was even completely lacking in the erf mutants (Fig. 6c) but the gene was still cold responsive at earlier time points although with a reduced amplitude as compared to wild type (Fig. S7). A proximity of the four $E R F$ genes to the CBF regulon was also suggested by the result of the network analysis which placed several proteins that are part of the CBF regulon $(\mathrm{CBF} 2 / \mathrm{DREB} 1 \mathrm{c}, \mathrm{ZAT} 10$ und RAP2.13/RAP2.4) in the vicinity of ERF102 to ERF105 (Fig. S6).

The lower activation of the $C B F$ and $C O R$ genes in coldacclimated $\operatorname{erf}$ gene mutants could be at least partially due to enhanced expression of another gene belonging to the CBF regulon, ZAT12 (Fig. 6f). ZAT12 encodes a zinc-finger protein known to be a negative regulator of the $\mathrm{CBF}$ regulon and is usually induced in parallel with $C B F$ and $C O R$ genes providing a negative regulatory feedback loop (Vogel et al. 2005). The higher expression of ZAT12 in the erf higher order mutants suggests that these $E R F$ genes may act as negative regulators of ZAT12 expression and in this way as positive regulators of $C B F$ and $C O R$ genes. Notably, the ZAT12 gene does not possess the specific DNA-binding motif of ERF transcription factors, the GCC-box, in its promoter region (Hao et al. 1998) suggesting that additional factors might be required for its repression by ERFs.

Knockout/knockdown of single ERF102 to ERF104 genes did not cause an altered transcript level of cold-responsive genes after 14 day of cold acclimation (Fig. S4), which is again in line with the assumption that these $E R F$ genes may have redundant roles. Lines overexpressing ERF102 to ERF104 did neither show a differential expression of coldresponsive genes nor an altered freezing tolerance (Fig. S4 and S5), similar to ERF105 overexpressing lines (Bolt et al. 2017). It is possible that ERF102 to ERF105 are required for the transcriptional activation of these target genes but are not the rate-limiting factors, for example because they function as part of a complex. Alternatively, activity of these proteins under cold may depend on additional regulatory steps such as phosphorylation which could be transient. Indeed, the phosphorylation of ERF102 to ERF104 by MPK3 and/or MPK6 was shown (Bethke et al. 2009; Son et al. 2012; Wang et al. 2013) and functions of MPK3 and MPK6 in the cold signalling pathway have been described (Kim et al. 2017; Li et al. 2017; Zhao et al. 2017).

Taken together, the data document similar and possibly partially redundant functions of ERF102 to ERF105 in response to cold. Notably, combined action of related $E R F$ 
transcription factor genes has also been reported in other cases (Jeon et al. 2016; Kim et al. 2016). Future work will investigate how the ERF102 to ERF105 proteins are integrated in the extensive transcriptional network governing the response to cold (Park et al. 2015; Jia et al. 2016; Zhao et al. 2016).

\section{Methods}

\section{Plant material}

Arabidopsis thaliana accession Col-0 was used as wild type. The erf105 mutant, ERF105 overexpressing lines, pERF 105:GUS lines, complementation lines of erf105, as well as 35S:ami104 and 35S:ami104/105 lines have been described previously (Bolt et al. 2017). The T-DNA insertion line erf102 (SAIL_46_C02) was obtained from the Nottingham Arabidopsis Stock Centre (NASC). After selection of homozygous plants, the location of the T-DNA insertion was verified by sequencing and plants were backcrossed twice with Col-0 to eliminate possible multiple insertions and other background mutations. Complementation of the erf102 phenotype was tested by introgressing ERF102ox-1 and ERF102ox-2 into the erf102 background. To generate lines overexpressing ERF102 to ERF104, the genomic coding sequences of ERF102 to ERF104 were amplified by PCR, cloned into pDONR221 (Invitrogen, Carlsbad, USA) by using the Gateway cloning system and transferred subsequently into vector pK7WGF2 (Karimi et al. 2007b). To generate $p E R F 102$ :GUS to $p E R F 104: G U S$ reporter genes, the promoter regions of the $E R F$ genes $(\sim 2 \mathrm{~kb}$ upstream of the start codon) were amplified by PCR and cloned into pDONR P4-P1R (Invitrogen). To generate the binary destination vectors, the pDONR P4-P1R constructs with the ERF promoters and the Gateway entry clone pEN-L1-SI-L2 (Karimi et al. 2007a) harboring the GUS reporter gene were then combined into the destination vector $\mathrm{pK} 7 \mathrm{~m} 24 \mathrm{GW}, 3$ using MultiSite Gateway (Karimi et al. 2005). Artificial microRNA (amiRNA) was used to generate lines with a reduced ERF103 expression (Schwab et al. 2006). amiRNAs directed against ERF 104 and ERF105 were described (Bolt et al. 2017). The amiRNA sequence targeting ERF103 was 5'-TAACGTCGTAACTTTCCCCCG-3'. The sequence was selected and the expression construct was made using the Web MicroRNA Designer (WMD3) and the protocol available under https://wmd3.weigelworld.org. The amiRNA precursor was cloned into pDONR221 (Invitrogen) and subsequently into pH2GW7 (Karimi et al. 2007b) harboring the cauliflower mosaic virus (CaMV) $35 \mathrm{~S}$ promoter to yield 35S:ami103. All primers used for cloning are listed in Table S1. The binary constructs were transformed into Col-0 plants by Agrobacterium tumefaciens (GV3101:pMP90) using the floral dip method as described by Davis et al. (2009). Higher order mutants with reduced expression of $E R F$ genes were generated by crossing amiRNA lines with T-DNA insertion lines.

\section{Growth conditions, hormone and stress treatment}

For hormone and stress treatments, plants were grown in vitro under long day (LD) conditions ( $16 \mathrm{~h}$ light $/ 8 \mathrm{~h}$ dark) and $21^{\circ} \mathrm{C}$ in half strength liquid Murashige and Skoog (MS) medium (for hormone treatment) or on solid MS medium (for stress treatment), in each case containing $0.1 \%$ sucrose (Murashige and Skoog 1962). Eleven days after germination (DAG), hormonal treatments were performed by adding the respective hormone to the liquid medium. Seedlings grown on solid medium were exposed to different stress treatments eleven DAG, including heat treatment at $42{ }^{\circ} \mathrm{C}$ in darkness, high light stress $\left(1000 \mu \mathrm{mol} \mathrm{m} \mathrm{m}^{-2} \mathrm{~s}^{-1}\right)$ instead of standard light $\left(100-150 \mu \mathrm{mol} \mathrm{m} \mathrm{m}^{-2} \mathrm{~s}^{-1}\right)$, oxidative stress by spraying seedlings with $500 \mathrm{mM} \mathrm{H}_{2} \mathrm{O}_{2}$ or transferring seedlings to liquid medium with $30 \mu \mathrm{M}$ paraquat, drought stress by transferring seedlings to dry filter paper, or salt/osmotic stress by transplanting seedlings to MS medium including $200 \mathrm{mM}$ $\mathrm{NaCl}$ or $200 \mathrm{mM}$ mannitol, respectively, for different time periods. Control plants were treated with the respective control conditions, which were the respective mock solution in the hormone experiment, $21^{\circ} \mathrm{C}$ in the heat stress experiment, standard light conditions in the high light experiment, spraying with mock solution in the $\mathrm{H}_{2} \mathrm{O}_{2}$ experiment, and transferring to moist filter paper in the drought experiment, or mock medium in the paraquat, salt and osmotic stress experiments.

For the analysis of growth and developmental parameters, plants were grown on soil in the greenhouse under LD conditions ( $16 \mathrm{~h}$ light $/ 8 \mathrm{~h}$ dark $)$ at a light intensity of $130-160 \mu \mathrm{mol} \mathrm{m} \mathrm{m}^{-2} \mathrm{~s}^{-1}$ and $21^{\circ} \mathrm{C}$. Fourteen, 21, 28, and 35 DAG rosette diameter and shoot height were determined. Furthermore, the flowering time, defined as opening of the first flower, was recorded. Leaf senescence was recorded based on visual inspection of the oldest leaves turning yellow.

For analysis of roots, plants were grown in vitro in vertically placed square petri dishes on half strength MS medium containing $10 \mathrm{~g} \mathrm{~L}^{-1}$ phytagel. The elongation of the primary root was determined from digital images between four and ten DAG using the software ImageJ (Abràmoff et al. 2004). The number of lateral roots was determined ten DAG from the same images.

For electrolyte leakage experiments, plants were grown for two weeks under SD conditions and then for four weeks under $\mathrm{LD}$ conditions at $200 \mu \mathrm{mol} \mathrm{m} \mathrm{s}^{-2} \mathrm{~s}^{-1}$ and $20^{\circ} \mathrm{C}$ during the day, $18{ }^{\circ} \mathrm{C}$ during the night (non-acclimated plants). For cold acclimation, plants were transferred to a cold chamber 
and cultivated under $\operatorname{LD}\left(90 \mu \mathrm{mol} \mathrm{m}{ }^{-2} \mathrm{~s}^{-1}\right)$ at $4{ }^{\circ} \mathrm{C}$ for additional 14 days.

\section{RNA analysis}

Total RNA was extracted from tissues using the NucleoSpin RNA Plant Kit (Macherey \& Nagel, Düren, Germany) according to the manufacturer's instructions, including an on-column DNase digestion. As a control, quantitative realtime PCR (qRT-PCR) measurements using intron-specific primers for AT5G65080 were performed to confirm the absence of genomic DNA contamination (Zuther et al. 2012). For RT-PCR, 500 ng RNA were reverse transcribed using the QIAGEN OneStep RT-PCR Kit according to the manufacturer's information (Qiagen, Hilden, Germany). The sequences of primers were as follows: Actin2-F, 5'-TACAAC GAGCTTCGTGTTGC-3'; Actin2-R, 5'-GATTGATCCTCC GATCCAGA-3'; ERF 102-F, 5'-CTGCACTTTGGTTCA TCGAG-3'; ERF102-R, 5'-GAGATAACGGCGACAGAA GC-3'. For qRT-PCR analyses, $1 \mu \mathrm{g}$ RNA was transcribed into cDNA by SuperScript III Reverse Transcriptase (Invitrogen) according to the manufacturer's instructions using a combination of oligo(dT) primers and random hexamers. qRT-PCR analyses were performed as previously described by Bolt et al. (2017). Four biological replicates were used and each qRT-PCR experiment was performed twice. In all cases both experiments yielded similar results and one result is shown exemplarily.

\section{GUS staining and microscopy}

Histochemical analysis to detect GUS reporter enzyme activity was performed as described by Jefferson et al. (1987) with some modifications as described by Bolt et al. (2017). GUS analyses were carried out with two or three independent $p E R F: G U S$ lines for each of the constructs and identical expression patterns were seen. The histochemical analyses were repeated several times with plants of different age.

\section{Promoter sequence analysis}

Analysis of the ERF102 to ERF105 promoters for the presence of cis-acting regulatory elements (CAREs) was carried out using the PLACE website (https://www.dna.affrc.go.jp/ PLACE/; Higo et al. 1998). The MotifMapper of the TOUCAN2 workbench (Aerts et al. 2005) was used to determine the frequency of CAREs in $2 \mathrm{~kb}$ of the ERF102 to ERF105 promoters ( $p E R F 102$ to $p E R F 105$ ).

\section{Transient gene expression in Nicotiana benthamiana and confocal laser scanning microscopy}

Subcellular localisation of GFP fused to ERF proteins was done in leaves of 6-week-old $N$. benthamiana according to Sparkes et al. (2006) with the equipment described by Bolt et al. (2017).

\section{Electrolyte leakage}

Electrolyte leakage was determined with detached leaves over a temperature range from -1 to $-16{ }^{\circ} \mathrm{C}$ for non-acclimated plants and from -2 to $-22{ }^{\circ} \mathrm{C}$ for cold acclimated plants, cooled at a rate of $4{ }^{\circ} \mathrm{Ch}^{-1}$ as described by detail in Rohde et al. (2004) and Thalhammer et al. (2014). Four technical replicates were analysed for each temperature point, and for each of these replicates leaves from three different plants were pooled. The temperature of 50\% electrolyte leakage $\left(\mathrm{LT}_{50}\right)$ was calculated as the log EC50 value of sigmoidal curves fitted to the leakage values using the software GraphPad Prism3 (GraphPad Software, Inc., La Jolla, USA).

\section{Statistical analyses}

Every experiment was conducted at least twice. Figures show data of a single experiment that is representative of two or three experiments showing similar results. Data are presented as the mean \pm standard error. Statistical analyses were performed using SAS or GraphPad Instat Software (one-way ANOVA or two-way repeated measures ANOVA with Tukey's post hoc test). Normality and homogeneity of variance were tested using the Shapiro-Wilk and Levene tests (Neter et al. 1996). In order to meet the assumptions, data sets were transformed using log or square-root transformation. If assumptions were not met, a nonparametric Kruskal-Wallis test was carried out followed by a Mann-Whitney test to perform a pairwise comparison.

Acknowledgements Open Access funding provided by Projekt DEAL. We acknowledge funding by Deutsche Forschungsgemeinschaft (Collaborative Research Centre 973, http://www.sfb.973).

Author Contributions SI, SZ and TS developed the project, SI designed and performed experiments, partly together with SZ, EZ and DH provided equipment and supported electrolyte leakage measurements, SI and TS analysed data, SI and TS wrote the article, all other authors read and contributed to previous versions and approved the final version.

Open Access This article is licensed under a Creative Commons Attribution 4.0 International License, which permits use, sharing, adaptation, distribution and reproduction in any medium or format, as long as you give appropriate credit to the original author(s) and the source, provide a link to the Creative Commons licence, and indicate if changes were made. The images or other third party material in this article are included in the article's Creative Commons licence, unless indicated otherwise in a credit line to the material. If material is not included in 
the article's Creative Commons licence and your intended use is not permitted by statutory regulation or exceeds the permitted use, you will need to obtain permission directly from the copyright holder. To view a copy of this licence, visit http://creativecommons.org/licenses/by/4.0/.

\section{References}

Abe H, Yamaguchi-Shinozaki K, Urao T, Iwasaki T, Hosokawa D, Shinozaki K (1997) Role of Arabidopsis MYC and MYB homologs in drought- and abscisic acid-regulated gene expression. Plant Cell 9:1859-1868. https://doi.org/10.1105/tpc.9.10.1859

Abe H, Urao T, Ito T, Seki M, Shinozaki K, Yamaguchi-Shinozaki K (2003) Arabidopsis AtMYC2 (bHLH) and AtMYB2 (MYB) function as transcriptional activators in abscisic acid signaling. Plant Cell 15:63-78. https://doi.org/10.1105/tpc.006130

Abràmoff MD, Magalhaes PJ, Ram SJ (2004) Image processing with ImageJ. Biophotonics Int 11:36-43

Aerts S, Van Loo P, Thijs G, Mayer H, de Martin R, Moreau Y, De Moor B (2005) TOUCAN 2: the all-inclusive open source workbench for regulatory sequence analysis. Nucleic Acids Res 33:393-396. https://doi.org/10.1093/nar/gki354

Agarwal M, Hao Y, Kapoor A, Dong CH, Fujii H, Zheng X, Zhu JK (2006a) A R2R3 type MYB transcription factor is involved in the cold regulation of $C B F$ genes and in acquired freezing tolerance. J Biol Chem 281:37636-37645. https://doi.org/10.1074/jbc. M605895200

Agarwal PK, Agarwal P, Reddy MK, Sopory SK (2006b) Role of DREB transcription factors in abiotic and biotic stress tolerance in plants. Plant Cell Rep 25:1263-1274. https://doi.org/10.1007/ s00299-006-0204-8

Baker SS, Wilhelm KS, Thomashow MF (1994) The 5'-region of Arabidopsis thaliana cor15a has cis-acting elements that confer cold-, drought- and ABA-regulated gene expression. Plant Mol Biol 24:701-713. https://doi.org/10.1007/bf00029852

Benfey PN (2016) Defining the path from stem cells to differentiated tissue. Curr Top Dev Biol 116:35-43. https://doi.org/10.1016/ bs.ctdb.2015.12.002

Benková E, Michniewicz M, Sauer M, Teichmann T, Seifertová D, Jürgens G, Friml J (2003) Local, efflux-dependent auxin gradients as a common module for plant organ formation. Cell 115:591-602. https://doi.org/10.1016/s0092-8674(03)00924-3

Bethke G, Unthan T, Uhrig JF, Pöschl Y, Gust AA, Scheel D, Lee J (2009) Flg22 regulates the release of an ethylene response factor substrate from MAP kinase 6 in Arabidopsis thaliana via ethylene signaling. Proc Natl Acad Sci USA 106:8067-8072. https://doi. org/10.1073/pnas.0810206106

Bolt S, Zuther E, Zintl S, Hincha DK, Schmülling T (2017) ERF105 is a transcription factor gene of Arabidopsis thaliana required for freezing tolerance and cold acclimation. Plant Cell Environ 40:108-120. https://doi.org/10.1111/pce.12838

Brenner WG, Romanov GA, Köllmer I, Bürkle L, Schmülling T (2005) Immediate-early and delayed cytokinin response genes of Arabidopsis thaliana identified by genome-wide expression profiling reveal novel cytokinin-sensitive processes and suggest cytokinin action through transcriptional cascades. Plant J 44:314-333. https://doi.org/10.1111/j.1365-313X.2005.02530.x

Cao FY, Khan M, Taniguchi M, Mirmiran A, Moeder W, Lumba S, Yoshioka K, Desveaux D (2019) A host-pathogen interactome uncovers phytopathogenic strategies to manipulate plant ABA responses. Plant J 100:187-198. https://doi.org/10.1111/ tpj. 14425

Casimiro I, Beeckman T, Graham N, Bhalerao R, Zhang H, Casero P, Sandberg G, Bennett MJ (2003) Dissecting Arabidopsis lateral root development. Trends Plant Sci 8:165-171. https:// doi.org/10.1016/S1360-1385(03)00051-7

Chang L, Ramireddy E, Schmülling T (2013) Lateral root formation and growth of Arabidopsis is redundantly regulated by cytokinin metabolism and signalling genes. J Exp Bot 64:5021-5032. https ://doi.org/10.1093/jxb/ert291

Chang L, Ramireddy E, Schmülling T (2015) Cytokinin as a positional cue regulating lateral root spacing in Arabidopsis. J Exp Bot 66:4759-4768. https://doi.org/10.1093/jxb/erv252

Chen C, Chen Z (2002) Potentiation of developmentally regulated plant defense response by AtWRKY18, a pathogen-induced Arabidopsis transcription factor. Plant Physiol 129:706-716. https://doi. org/10.1104/pp.001057

Chinnusamy V, Ohta M, Kanrar S, Lee BH, Hong X, Agarwal M, Zhu JK (2003) ICE1: a regulator of cold-induced transcriptome and freezing tolerance in Arabidopsis. Genes Dev 17:1043-1054. https ://doi.org/10.1101/gad.1077503

Chinnusamy V, Zhu J, Zhu JK (2007) Cold stress regulation of gene expression in plants. Trends Plant Sci 12:444-451. https://doi. org/10.1016/j.tplants.2007.07.002

Davis AM, Hall A, Millar AJ, Darrah C, Davis SJ (2009) Streamlined subprotocols for floral-dip transformation and selection of transformants in Arabidopsis thaliana. Plant Methods 5:1-7. https:// doi.org/10.1186/1746-4811-5-3

Despres C, Chubak C, Rochon A, Clark R, Bethune T, Desveaux D, Fobert PR (2003) The Arabidopsis NPR1 disease resistance protein is a novel cofactor that confers redox regulation of DNA binding activity to the basic domain/leucine zipper transcription factor TGA1. Plant Cell 15:2181-2191. https://doi.org/10.1105/ tpc. 012849

Di Laurenzio L, Wysocka-Diller J, Malamy JE, Pysh L, Helariutta Y, Freshour G, Hahn MG, Feldmann KA, Benfey PN (1996) The SCARECROW gene regulates an asymmetric cell division that is essential for generating the radial organization of the Arabidopsis root. Cell 86:423-433. https://doi.org/10.1016/s0092 -8674(00)80115-4

Ding Y, Li H, Zhang X, Xie Q, Gong Z, Yang S (2015) OST1 kinase modulates freezing tolerance by enhancing ICE1 stability in Arabidopsis. Dev Cell 3:278-289. https://doi.org/10.1016/j.devce 1.2014.12.023

Doherty CJ, Van Buskirk HA, Myers SJ, Thomashow MF (2009) Roles for Arabidopsis CAMTA transcription factors in cold-regulated gene expression and freezing tolerance. Plant Cell 21:972-984. https://doi.org/10.1105/tpc.108.063958

Dubois M, Skirycz A, Claeys H, Maleux K, Dhondt S, De Bodt S, Vanden Bossche R, De Milde L, Yoshizumi T, Matsui M, Inzé D (2013) Ethylene Response Factor6 acts as a central regulator of leaf growth under water-limiting conditions in Arabidopsis. Plant Physiol 162:319-332. https://doi.org/10.1104/pp.113.216341

Dubois M, Van den Broeck L, Claeys H, Van Vlierberghe K, Matsui M, Inzé D (2015) The ETHYLENE RESPONSE FACTORS ERF6 and ERF11 antagonistically regulate mannitol-induced growth inhibition in Arabidopsis. Plant Physiol 169:166-179. https:// doi.org/10.1104/pp.15.00335

Edgar RC (2004) MUSCLE: multiple sequence alignment with high accuracy and high throughput. Nucleic Acids Res 32:1792-1797. https://doi.org/10.1093/nar/gkh340

Fujimoto SY, Ohta M, Usui A, Shinshi H, Ohme-Takagi M (2000) Arabidopsis ethylene responsive element binding factors act as transcriptional activators or repressors of GCC box-mediated gene expression. Plant Cell 12:393-404. https://doi.org/10.1105/ tpc. 12.3.393

Fursova OV, Pogorelko GV, Tarasov VA (2009) Identification of ICE2, a gene involved in cold acclimation which determines freezing tolerance in Arabidopsis thaliana. Gene 429:98-103. https://doi. org/10.1016/j.gene.2008.10.016 
Hao D, Ohme-Takagi M, Sarai A (1998) Unique mode of GCC box recognition by the DNA-binding domain of ethylene-responsive element-binding factor (ERF domain) in plants. J Biol Chem 273:26857-26861. https://doi.org/10.1074/jbc.273.41.26857

Haralampidis K, Milioni D, Rigas S, Hatzopoulos P (2002) Combinatorial interaction of cis elements specifies the expression of the Arabidopsis AtHsp90-1 gene. Plant Physiol 129:1138-1149. https ://doi.org/10.1104/pp.004044

Higo K, Ugawa Y, Iwamoto M, Higo H (1998) PLACE: a database of plant cis-acting regulatory DNA elements. Nucleic Acids Res 26:358-359. https://doi.org/10.1093/nar/26.1.358

Horton P, Park KJ, Obayashi T, Fujita N, Harada H, Adams-Collier CJ, Nakai K (2007) WoLF PSORT: protein localization predictor. Nucleic Acids Res 35:585-587. https://doi.org/10.1093/nar/ gkm259

Huala E, Dickerman AW, Garcia-Hernandez M, Weems D, Reiser L, LaFond F, Hanley D, Kiphart D, Zhuang M, Huang W, Mueller LA, Bhattacharyya D, Bhaya D, Sobral BW, Beavis W, Meinke DW, Town CD, Somerville C, Rhee SY (2001) The Arabidopsis Information Resource (TAIR): a comprehensive database and web-based information retrieval, analysis, and visualization system for a model plant. Nucleic Acids Res 2:102-105. https://doi. org/10.1093/nar/29.1.102

Jefferson RA, Kavanagh TA, Bevan MW (1987) GUS fusions: beta-glucuronidase as a sensitive and versatile gene fusion marker in higher plants. EMBO J 6:3901-3907. https://doi. org/10.1002/j.1460-2075.1987.tb02730.x

Jeon J, Cho C, Lee MR, Van Binh N, Kim J (2016) CYTOKININ RESPONSE FACTOR2 (CRF2) and CRF3 regulate lateral root development in response to cold stress in Arabidopsis. Plant Cell 28:1828-1843. https://doi.org/10.1105/tpc.15.00909

Jia Y, Ding Y, Shi Y, Zhang X, Gong Z, Yang S (2016) The $c b f$ s triple mutants reveal the essential functions of CBFs in cold acclimation and allow the definition of CBF regulons in Arabidopsis. New Phytol 212:345-353. https://doi.org/10.1111/nph.14088

Karimi M, De Meyer B, Hilson P (2005) Modular cloning in plant cells. Trends Plant Sci 10:103-105. https://doi.org/10.1016/j.tplan ts.2005.01.008

Karimi B, Bleys A, Vanderhaeghen R, Hilson P (2007a) Building blocks for plant gene assembly. Plant Physiol 145:1183-1191. https://doi.org/10.1104/pp.107.110411

Karimi M, Depicker A, Hilson P (2007b) Recombinational cloning with plant Gateway vectors. Plant Physiol 145:1144-1154. https ://doi.org/10.1104/pp.107.106989

Kim SH, Kim HS, Bahk S, An J, Yoo Y, Kim JY, Chung WS (2017) Phosphorylation of the transcriptional repressor MYB15 by mitogen-activated protein kinase 6 is required for freezing tolerance in Arabidopsis. Nucleic Acids Res 45:6613-6627. https://doi. org/10.1093/nar/gkx417

Kim NY, Jang YJ, Park OK (2018) AP2/ERF family transcription factors ORA59 and RAP2.3 interact in the nucleus and function together in ethylene responses. Front Plant Sci 19:1675

Kizis D, Lumbreras V, Pagès M (2001) Role of AP2/EREBP transcription factors in gene regulation during abiotic stress. FEBS Lett 498:187-189. https://doi.org/10.1016/s0014-5793(01)02460-7

Li H, Ding Y, Shi Y, Zhang X, Zhang S, Gong Z, Yang S (2017) MPK3and MPK6-mediated ICE1 phosphorylation negatively regulates ICE1 stability and freezing tolerance in Arabidopsis. Dev Cell 43:630-642. https://doi.org/10.1016/j.devcel.2017.09.025

Lee B, Henderson DA, Zhua J (2005) The Arabidopsis cold-responsive transcriptome and its regulation by ICE1. Plant Cell 17:31553175. https://doi.org/10.1105/tpc. 105.035568

Licausi F, Ohme-Takagi M, Perata P (2013) APETALA2/Ethylene Responsive Factor (AP2/ERF) transcription factors: mediators of stress responses and developmental programs. New Phytol 199:639-649. https://doi.org/10.1111/nph.12291
Liu Q, Kasuga M, Sakuma Y, Abe H, Miura S, Yamaguchi-Shinozaki K, Shinozaki K (1998) Two transcription factors, DREB1 and DREB2, with an EREBP/AP2 DNA binding domain separate two cellular signal transduction pathways in drought- and low-temperature-responsive gene expression, respectively, in Arabidopsis. Plant Cell 10:1391-1406. https://doi.org/10.1105/tpc.10.8.1391

Maruyama K, Todaka D, Mizoi J, Yoshida T, Kidokoro S, Matsukura S, Takasaki H, Sakurai T, Yamamoto YY, Yoshiwara K, Kojima M, Sakakibara H, Shinozaki K, Yamaguchi-Shinozaki K (2012) Identification of $c i s$-acting promoter elements in cold- and dehydration-induced transcriptional pathways in Arabidopsis, rice, and soybean. DNA Res 19:37-49. https://doi.org/10.1093/dnare s/dsr040

Mase K, Ishihama N, Mori H, Takahashi H, Kaminaka H, Kodama M, Yoshioka H (2013) Ethylene-responsive AP2/ERF transcription factor MACD1 participates in phytotoxin-triggered programmed cell death. Mol Plant Microbe Interact 26:868-879. https://doi. org/10.1094/MPMI-10-12-0253-R

Meng X, Xu J, He Y, Yang KY, Mordorski B, Liu Y, Zhang S (2013) Phosphorylation of an ERF transcription factor by Arabidopsis MPK3/MPK6 regulates plant defense gene induction and fungal resistance. Plant Cell 25:1126-1142. https://doi.org/10.1105/ tpc.112.109074

Miura K, Jin JB, Lee J, Yoo CY, Stirm V, Miura T, Ashworth EN, Bressan RA, Yun DJ, Hasegawa PM (2007) SIZ1-mediated sumoylation of ICE1 controls CBF3/DREB1A expression and freezing tolerance in Arabidopsis. Plant Cell 19:1403-1414. https://doi. org/10.1105/tpc.106.048397

Moffat CS, Ingle RA, Wathugala DL, Saunders NJ, Knight H, Knight MR (2012) ERF5 and ERF6 play redundant roles as positive regulators of JA/Et-mediated defense against Botrytis cinerea in Arabidopsis. PLoS ONE 7:e35995. https://doi.org/10.1371/journ al.pone.0035995

Moore MO, König K, Pecher P, Alsharafa K, Lee J, Dietz KJ (2014a) Fast retrograde signaling in response to high light involves metabolite export, MITOGEN-ACTIVATED PROTEIN KINASE6, and AP2/ERF transcription factors in Arabidopsis. Plant Cell 26:1151-1165. https://doi.org/10.1105/tpc.113.121061

Moore M, Vogel M, Dietz K (2014b) The acclimation response to high light is initiated within seconds as indicated by upregulation of AP2/ERF transcription factor network in Arabidopsis thaliana. Plant Signal Behav 9:976479. https://doi.org/10.4161/15592 324.2014.976479

Motte H, Vanneste S, Beeckman T (2019) Molecular and environmental regulation of root development. Annu Rev Plant Biol 70:465488. https://doi.org/10.1146/annurev-arplant-050718-100423

Müller M, Munné-Bosch S (2015) Ethylene response factors: a key regulatory hub in hormone and stress signaling. Plant Physiol 169:32-41. https://doi.org/10.1104/pp.15.00677

Murashige T, Skoog F (1962) A revised medium for rapid growth and bioassays with tobacco tissue cultures. Physiol Plant 15:473-497. https://doi.org/10.1111/j.1399-3054.1962.tb08052.x

Nakano T, Suzuki K, Fujimura T, Shinshi H (2006) Genome-wide analysis of the ERF gene family in Arabidopsis and rice. Plant Physiol 140:411-432. https://doi.org/10.1104/pp.105.073783

Neter J, Kutner MH, Nachtsheim CJ, Wasserman W (1996) Applied linear statistic models. McGraw-Hill, New York

Ogawa M, Hanada A, Yamauchi Y, Kuwahara A, Kamiya Y, Yamaguchi S (2003) Gibberellin biosynthesis and response during Arabidopsis seed germination. Plant Cell 15:1591-1604. https://doi. org/10.1105/tpc. 011650

Ohme-Takagi M, Shinshi H (1995) Ethylene-inducible DNA binding proteins that interact with an ethylene-responsive element. Plant Cell 7:173-182. https://doi.org/10.1105/tpc.7.2.173

Park S, Lee CM, Doherty CJ, Gilmour SJ, Kim Y, Thomashow MF (2015) Regulation of the Arabidopsis CBF regulon by a complex 
low-temperature regulatory network. Plant J 82:193-207. https:// doi.org/10.1111/tpj.12796

Péret B, De Rybel B, Casimiro I, Benková E, Swarup R, Laplaze L, Beeckman T, Bennett MJ (2009) Arabidopsis lateral root development: an emerging story. Trends Plant Sci 14:399-408. https://doi. org/10.1016/j.tplants.2009.05.002

Riechmann JL, Meyerowitz EM (1998) The AP2/EREBP family of plant transcription factors. Biol Chem 379:6336-6346. https:// doi.org/10.1515/bchm.1998.379.6.633

Riechmann JL, Heard J, Martin G, Reuber L, Jiang C, Keddie J, Adam L, Pineda O, Ratcliffe OJ, Samaha RR, Creelman R, Pilgrim M, Broun P, Zhang JZ, Ghandehari D, Sherman BK, Yu G (2000) Arabidopsis transcription factors: genome-wide comparative analysis among eukaryotes. Science 290:2105-2110. https://doi. org/10.1126/science.290.5499.2105

Rohde P, Hincha DK, Heyer AG (2004) Heterosis in the freezing tolerance of crosses between two Arabidopsis thaliana accessions (Columbia-0 and C24) that show differences in non-acclimated and acclimated freezing tolerance. Plant J 38:790-799. https://doi. org/10.1111/j.1365-313X.2004.02080.x

Sakai H, Aoyama T, Oka A (2000) Arabidopsis ARR1 and ARR2 response regulators operate as transcriptional activators. Plant $\mathrm{J}$ 24:703-711. https://doi.org/10.1046/j.1365-313x.2000.00909.x

Salvi E, Di Mambro R, Pacifici E, Dello Ioio R, Costantino P, Moubayidin L, Sabatini S (2018) SCARECROW and SHORTROOT control the auxin/cytokinin balance necessary for embryonic stem cell niche specification. Plant Signal Behav 13:e1507402. https:// doi.org/10.1080/15592324.2018.1507402

Schwab R, Ossowski S, Riester M, Warthmann N, Weigel D (2006) Highly specific gene silencing by artificial microRNAs in Arabidopsis. Plant Cell 18:1121-1133. https://doi.org/10.1105/ tpc. 105.039834

Sewelam N, Kazan K, Thomas-Hall SR, Kidd BN, Manners JM, Schenk PM (2013) Ethylene response factor 6 is a regulator of reactive oxygen species signaling in Arabidopsis. PLoS ONE 8:e70289. https://doi.org/10.1371/journal.pone.0070289

Shen Q, Ho TH (1995) Functional dissection of an abscisic acid (ABA)-inducible gene reveals two independent ABA-responsive complexes each containing a G-box and a novel cis-acting element. Plant Cell 7:295-307. https://doi.org/10.1105/tpc.7.3.295

Son GH, Wan J, Kim HJ, Nguyen XC, Chung WS, Hong JC, Stacey G (2012) Ethylene-responsive element-binding factor 5, ERF5, is involved in chitin-induced innate immunity response. Mol Plant Microbe Interact 25:48-60. https://doi.org/10.1094/ MPMI-06-11-0165

Sparkes IA, Runions J, Kearns A, Hawes C (2006) Rapid, transient expression of fluorescent fusion proteins in tobacco plants and generation of stably transformed plants. Nat Protoc 1:2019-2025. https://doi.org/10.1038/nprot.2006.286

Sparks EE, Drapek C, Gaudinier A, Li S, Ansariola M, Shen N, Hennacy JH, Zhang J, Turco G, Petricka JJ, Foret J, Hartemink AJ, Gordân R, Megraw M, Brady SM, Benfey PN (2016) Establishment of expression in the SHORTROOT-SCARECROW transcriptional cascade through opposing activities of both activators and repressors. Dev Cell 39:585-596. https://doi.org/10.1016/j. devcel.2016.09.031

Srivastava R, Kumar R (2019) The expanding roles of APETALA2/ Ethylene Responsive Factors and their potential applications in crop improvement. Brief Funct Genomics 18:240-254. https:// doi.org/10.1093/bfgp/elz001

Steinert J, Schiml S, Fauser F, Puchta H (2015) Highly efficient heritable plant genome engineering using Cas9 orthologues from Streptococcus thermophilus and Staphylococcus aureus. Plant J 84:1295-1305. https://doi.org/10.1111/tpj.13078

Swarup K, Benková E, Swarup R, Casimiro PB, Yang Y, Parry G, Nielsen E, De Smet I, Vanneste S, Levesque MP, Carrier D, James
N, Calvo V, Ljung K, Kramer E, Roberts R, Graham N, Marillonnet S, Patel K, Jones JD, Taylor CG, Schachtman DP, May S, Sandberg G, Benfey P, Friml J, Kerr I, Beeckman T, Laplaze L, Bennett MJ (2008) The auxin influx carrier LAX3 promotes lateral root emergence. Nat Cell Biol 10:946-954. https://doi. org/10.1038/ncb1754

Tamura K, Stecher G, Peterson D, Filipski A, Kumar S (2013) MEGA6: Molecular evolutionary genetics analysis version 6.0. Mol Biol Evol 30:2725-2729. https://doi.org/10.1093/molbev/mst197

Taniguchi M, Sasaki N, Tsuge T, Aoyama T, Oka A (2007) ARR1 directly activates cytokinin response genes that encode proteins with diverse regulatory functions. Plant Cell Physiol 48:263-277. https://doi.org/10.1093/pcp/pc1063

Thalhammer A, Hincha DK, Zuther E (2014) Measuring freezing tolerance: electrolyte leakage and chlorophyll fluorescence assays. Methods Mol Biol 1166:15-24. https://doi. org/10.1007/978-1-4939-0844-8_3

Thomashow MF (1999) Plant cold acclimation: freezing tolerance genes and regulatory mechanisms. Annu Rev Plant Physiol Plant Mol Biol 50:571-599. https://doi.org/10.1146/annurev.arpla nt.50.1.571

Urao T, Yamaguchi-Shinozaki K, Urao S, Shinozaki K (1993) An Arabidopsis myb homolog is induced by dehydration stress and its gene product binds to the conserved MYB recognition sequence. Plant Cell 5:1529-1539. https://doi.org/10.1105/tpc.5.11.1529

Vilarrasa-Blasi J, González-García MP, Frigola D, Fàbregas N, Alexiou KG, LópezBigas N, Rivas S, Jauneau A, Lohmann JU, Benfey PN, Ibañes M, Caño-Delgado AI (2014) Regulation of plant stem cell quiescence by a brassinosteroid signaling module. Dev Cell 30:36-47. https://doi.org/10.1016/j.devcel.2014.05.020

Vogel JT, Zarka DG, Van Buskirk HA, Fowler SG, Thomashow MF (2005) Roles of the CBF2 and ZAT12 transcription factors in configuring the low temperature transcriptome of Arabidopsis. Plant J 41:195-211. https://doi.org/10.1111/j.1365-313X.2004.02288.x

Vogel MO, Moore M, König K, Pecher P, Alsharafa K, Lee J, Dietz KJ (2014) Fast retrograde signaling in response to high light involves metabolite export, MITOGEN-ACTIVATED PROTEIN KINASE6, and AP2/ERF transcription factors in Arabidopsis. Plant Cell 26:1151-1165. https://doi.org/10.1105/tpc.113.121061

Wang P, Du Y, Zhao X, Miao Y, Song CP (2013) The MPK6-ERF6ROS-responsive cis-acting Element7/GCC box complex modulates oxidative gene transcription and the oxidative response in Arabidopsis. Plant Physiol 161:1392-1408. https://doi. org/10.1104/pp.112.210724

Warde-Farley D, Donaldson SL, Comes O, Zuberi K, Badrawi R, Chao P, Franz M, Grouios C, Kazi F, Lopes CT, Maitland A, Mostafavi S, Montojo J, Shao Q, Wright G, Bader GD, Morris Q (2010) The GeneMANIA prediction server: biological network integration for gene prioritization and predicting gene function. Nucleic Acids Res 38:214-220. https://doi.org/10.1093/nar/gkq537

Xie Z, Nolan TM, Jiang H, Yin Y (2019) AP2/ERF transcription factor regulatory networks in hormone and abiotic stress responses in Arabidopsis. Front Plant Sci 10:228. https://doi.org/10.3389/ fpls.2019.00228

Xin Z, Browse J (2000) Cold comfort farm: the acclimation of plants to freezing temperatures. Plant Cell Environ 23:893-902. https:// doi.org/10.1046/j.1365-3040.2000.00611.x

Yamaguchi-Shinozaki K, Shinozaki K (2006) Transcriptional regulatory networks in cellular responses and tolerance to dehydration and cold stresses. Annu Rev Plant Biol 57:781-803. https://doi. org/10.1146/annurev.arplant.57.032905.105444

Zhao C, Zhang Z, Xie S, Si T, Li Y, Zhu JK (2016) Mutational evidence for the critical role of CBF transcription factors in cold acclimation in Arabidopsis. Plant Physiol 171:2744-2759. https ://doi.org/10.1104/pp.16.00533 
Zhao C, Wang P, Si T, Hsu CC, Wang L, Zayed O, Yu Z, Zhu Y, Dong J, Tao WA, Zhu JK (2017) MAP kinase cascades regulate the cold response by modulating ICE1 protein stability. Dev Cell 43:618-629. https://doi.org/10.1016/j.devcel.2017.09.024

Zuther E, Schulz E, Childs L, Hincha DK (2012) Clinal variation in the non-acclimated and cold-acclimated freezing tolerance of Arabidopsis thaliana accessions. Plant Cell Environ 35:1860-1878. https://doi.org/10.1111/j.1365-3040.2012.02522.x
Publisher's Note Springer Nature remains neutral with regard to jurisdictional claims in published maps and institutional affiliations. 